\author{
UNIVERSIDADE DE SÃO PAULO \\ FACULDADE DE MEDICINA DE RIBEIRÃO PRETO \\ DEPARTAMENTO DE PATOLOGIA
}

\title{
Isoproterenol induz a perda primária de distrofina: correlação com a injúria miocárdica
}

ÉRICA CAROLINA CAMPOS

Ribeirão Preto

2008 


\section{ÉRICA CAROLINA CAMPOS}

\section{Isoproterenol induz a perda primária de distrofina: correlação com a injúria miocárdica}

Dissertação apresentada ao Departamento de Patologia da Faculdade de Medicina de Ribeirão Preto da Universidade de São Paulo para obtenção do título de Mestre em Patologia.

Área de Concentração: Patologia Experimental

Orientador: Prof. Dr. Marcos A. Rossi

Ribeirão Preto

2008 


\section{FICHA CATALOGRÁFICA}

\section{Campos, Érica Carolina}

Isoproterenol induz a perda primária de distrofina: correlação com a injúria miocárdica, 2008.

90 p. : il. ; $30 \mathrm{~cm}$

Dissertação de Mestrado, apresentada à Faculdade de Medicina de Ribeirão Preto/USP. Área de concentração: Patologia.

Orientador: Rossi, Marcos A.

1. Isoproterenol. 2. Distrofina. 3. Complexo de glicoproteínas. 4. Miocitólise. 5. Isquemia. 


\section{FOLHA DE APROVAÇÃO}

Érica Carolina Campos

Isoproterenol induz a perda primária de distrofina: correlação com a injúria miocárdica

Dissertação apresentada ao Departamento de Patologia da Faculdade de Medicina de Ribeirão Preto da Universidade de São Paulo para obtenção do título de Mestre em Patologia.

Área de Concentração: Patologia Experimental

Banca Examinadora

Prof. Dr.

Instituição:

Assinatura:

Prof. Dr.

Instituição:

Assinatura:

Prof. Dr.

Instituição: Assinatura: 


\section{DEDICATÓRIA}

Dedico este trabalho,

Aos meus pais Raquel e Valmyr, ao meu irmão Fabiano e à minha madrinha Maria Auxiliadora (Tia Dôra), presentes em todos os momentos da minha vida.

A vocês, que me deram tanto amor, que dividiram comigo cada momento difícil e que me deram as mãos para sustentar a minha fragilidade. Vocês que confiaram na minha conquista, e entenderam minha ausência em alguns momentos. Deus deu-me uma família que amo muito! 


\section{AGRADECIMENTO ESPECIAL}

Ao meu orientador Prof. Dr. Marcos A. Rossi

Uma pessoa perspicaz que sempre me diz pra não ter medo de errar e o quão importante é aprendermos a dourar a nossa pílula. Ser orientador não é apenas transmitir o profundo conhecimento, mas acima de tudo, ser um exemplo de dedicação, de doação e dignidade. Sou agradecida ao mestre que me iluminou, aqueceu e marcou presença. Nos instantes mais difíceis, tive a certeza do seu apoio transmitindo-me segurança para continuar e coragem para também errar. A minha profunda gratidão ao mestre e amigo. 


\section{AGRADECIMENTOS}

\section{A Deus.}

"Seu imenso carinho para conosco está no sol que nos aquece, dando sustento e alegria a todos os seres e a todas as coisas; nas nuvens que fazem a chuva para o contentamento da natureza; nas águas dos rios e das fontes, que deslizam para o benefício das cidades, dos campos e dos rebanhos; no pão que nos alimenta; na doçura do vento que refresca; na bondade das árvores que nos estendem os galhos dadivosos, em forma de braços ricos de bênçãos; na flor que espalha perfume na atmosfera; na ternura e na segurança de nosso lar; na assistência dos nossos pais, dos nossos irmãos e dos nossos amigos que nos ajudam a vencer as dificuldades do mundo e da vida, e na providência silenciosa, que nos garante a conservação da saúde e da paz espiritual" (Chico Xavier).

\section{À minha família de Belo Horizonte.}

Todos vocês que me deram apoio para que eu pudesse continuar e coragem para não desanimar.

\section{À Profa. Dra. Simone Gusmão Ramos.}

Por ter me aceitado como sua aluna no início do mestrado, pelas conversas e risadas durante as cirurgias experimentais, e por sempre ter acreditado na minha capacidade.

Às técnicas do Laboratório de Patologia Cardiovascular, Lígia G. V. B. Santoro, técnica em microscopia óptica de alta resolução; Mônica A. de Abreu, técnica em imunofluorescência, e Maria Helena Riul, técnica em microscopia óptica convencional.

Agradeço-lhes pelo carinho, paciência e pelo acolhimento desde quando entrei no laboratório como estagiária. A dedicação e experiência de vocês proporcionaram as imagens maravilhosas para este trabalho.

\section{À Dra. Minna M. D. Romano, da Divisão de Cardiologia do Hospital das Clínicas da Faculdade de Medicina de Ribeirão Preto.}

Pela disponibilidade e interesse na realização e análise das imagens ecocardiográficas. 


\section{À técnica do Departamento de Patologia Laura Midori Kawasse.}

Pela realização da técnica para detecção de apoptose (TUNEL).

Aos amigos do Laboratório de Patologia Cardiovascular: Mara R. N. Celes, Cibele M. Prado, Lenaldo Rocha, Gisele Faria, Andiara de Rossi e Valdecir Blefari (recém-chegado ao laboratório).

Obrigada pela amizade, pela ajuda nas minhas freqüentes dúvidas e medos, pelo conhecimento e experiência, pelas nossas conversas e discussões super produtivas nos horários de intervalo, pelos momentos especiais e alegres nos encontros fora do laboratório. Meu reconhecimento a vocês que quiseram o meu bem, escutando-me, auxiliando-me com o olhar atento e o coração aberto.

\section{À amiga Cibele M. Prado.}

Por ter aberto sua casa para mim quando me mudei pra Ribeirão Preto, e como ela mesma diz, "fomos companheiras de cela" durante dois anos. Agradeço o acolhimento, as preocupações e os conselhos que me deu.

Às amigas do Laboratório Patologia Pulmonar: Elaine M. Floriano, Cristina T. Beneli, Priscila F. Barbosa, Cristiane Tefé da Silva, Marcela S. Oliveira, Karina M. A. da Mata.

A amizade de vocês proporcionou momentos muito descontraídos, principalmente nos cursos básicos e avançados dos assuntos mais variados possíveis. Hoje somos bem mais do que companheiras de laboratório, somos todas amigas. Ressalto a formação das superpowers amigas, Cristina, Érica, Mara, Cristiane e Marcela.

\section{À amiga Tassiana Marini.}

Obrigada pelo companheirismo, amizade, maturidade, pela alegria contagiante e apoio dado nesse período mais conturbado de final de mestrado.

Às secretárias do Departamento de Patologia, Neide T. Gonçalves, Rosângela C. N. Paiva, Edna Pio (in memorian).

Que sempre estiveram disponíveis para me auxiliar, trazendo-me respostas e atendendo meus pedidos. 
Aos funcionários do Biotério da Patologia, Maria Aparecida C. Apolinário (D. Cida), Luciana G.A. Campanini, Paulo Henrique da Silva e Marileide de Souza.

Por cuidarem dos nossos animais com muito respeito e carinho. Vocês que na humildade das tarefas, talvez nem percebam a importância desse cuidado para o desenvolvimento dos nossos trabalhos.

\section{Às funcionários da limpeza, Rose, Karina, Vanessa, Diraci e Beatriz (Bia).}

Por manterem nosso ambiente de trabalho limpo e cheiroso todos os dias. Obrigada pelo bom dia, pelo sorriso no corredor, pela limpeza das salas e pelo apagar da luzes.

\section{Aos ex-professores e amigos José Alexandre Bachur e Cynthia K. Bachur.}

Agradeço em especial ao amigo José Alexandre por ter confiado na minha capacidade e ter me ensinado os primeiros passos na pesquisa. Junto com a Cynthia, vocês exerceram um papel importante na minha formação profissional e pessoal ensinando-me a prática do respeito e da humildade. Agradeço-lhes pela presença tão importante em todos os instantes dessa caminhada, transformando as minhas dúvidas em certezas, as tristezas em alegrias, a insegurança em confiança.

\section{Aos ex-professores e amigos do curso de Fisioterapia da Universidade de Franca.}

A vocês que sempre estiveram comigo renovando meus ideais e concretizando meus sonhos.

Às amigas de Franca, Ana Paula R. de Oliveira e Poliana Penasso Bezerra.

Amigas que conheci quando fizemos Residência na Universidade de Franca e, que desde então, não nos separamos mais. Obrigada pelo carinho, pelas conversas, pelo ombro amigo e pelos momentos de descontração, principalmente regados com um bom vinho.

Às amigas de Belo Horizonte, Renata da Cruz Ramos, Lílian da Cruz Ramos, Camila Nery, Janaína G. Nepomuceno.

Amigas que mesmo de longe, acompanharam e torceram por mim desde quando saí de Belo Horizonte. 
Às amigas de Franca, Leila S. de Oliveira, Ângela Melo (Angel), Mércia do Nascimento e Maria Aparecida Rossato (Cidinha).

Vocês caminharam comigo e muitas vezes tiveram que compreender minha pressa, compromissos, buscas e até mesmo mau humor e mesmo assim me incentivaram a continuar. Amigas, vocês são as melhores companheiras de viagem. Demos muitas risadas, temos muita história pra contar e espero que tenhamos muitas ainda.

Aos amigos de infância de Salto Osório.

Amigos desde a infância quando nossos pais trabalhavam juntos, que mandam vibrações positivas lá do sul do Brasil com todo carinho.

\section{À amiga Vanessa Silveira.}

Pelos nossos papos animados no messenger ou durante os cafés no shopping.

Aos amigos do Grupo de Estudo do Centro Espírita Benedito Rosa de Jesus, Beth, Ana Lúcia, Rogéro, Antônio, Sandra, Márcia, Paulo Roberto, Olga, José Carlos, Fátima, Meiga, Danielly e Lucila.

Aos poucos a convivência e as afinidades foram nos aproximando. Agradeço pela amizade de vocês, pela troca de experiência e por me darem força pra encarar os desafios diários. São amigos pra todas as horas. Nossos encontros e jantares são muito especiais, aprendo muito. Vocês foram imprescindíveis na realização deste meu sonho. Obrigada!

Ao Conselho Nacional de Desenvolvimento Científico e tecnológico (CNPq) e a Fundação de Apoio ao Ensino, Pesquisa e Assistência do Hospital das Clínicas da Faculdade de Medicina de Ribeirão Preto (FAEPA).

Pelo apoio financeiro que conscientemente aproveitei em todos os momentos.

Serei eternamente grata a todos vocês que sustentaram os meus vôos. 
"Somos anjos de uma asa só. Para decolarmos, temos que nos abraçar." (Mário Quintana) 


\section{RESUMO}

CAMPOS EC. Isoproterenol induz a perda primária de distrofina: correlação com a injúria miocárdica. 2008. 90f. Dissertação (Mestrado). Departamento de Patologia Faculdade de Medicina de Ribeirão Preto, Universidade de São Paulo, 2008.

Este estudo teve como objetivo avaliar as alterações do complexo de glicoproteínas associadas à distrofina que conferem estabilidade estrutural aos cardiomiócitos na isquemia miocárdica induzida pelo isoproterenol. Materiais e Métodos: Ratos Wistar machos foram divididos em dois grupos: grupo controle (SAL), injeção subcutânea de salina, e grupo isoproterenol (ISO), injeção subcutânea de isoproterenol $(85 \mathrm{mg} / \mathrm{kg})$ diluído em água destilada, em dois dias consecutivos separados por intervalo de $24 \mathrm{hs}$. Os ratos foram mortos 24 horas após a segunda injeção de salina ou isoproterenol. Os corações foram rapidamente excisados, lavados em salina gelada, pesados e colocados em formol PBS por $24 \mathrm{hs} \mathrm{a} 4^{\circ} \mathrm{C}$ e inclú́dos em parafina ou Historesina. Para análise morfométrica, os corações foram cortados transversalmente na porção medioventricular, equidistante entre o ápice e a base, e incluídos em parafina. Áreas dos ventrículos direito e esquerdo, espessura de parede livre dos ventrículos e septo interventricular foram medidas. Os corações cortados frontalmente nas metades anterior e posterior e incluídos em Historesina foram utilizados para avaliação das áreas de miocitólise. Porções hemiventriculares foram congeladas para as reações de imunofluorescência com os seguintes marcadores: distrofina, $\beta-1$ integrina, $\alpha-$ actina sarcomérica, $\gamma$-sarcoglicana, $\beta$-distroglicana, merosina laminina, albumina, CD68, CD45, CD4 e eNOS. A apoptose foi avaliada através do método de TUNEL. A função cardíaca, as dimensões das cavidades ventriculares e a mobilidade de parede foram analisadas através da ecocardiografia. A análise estatística foi realizada através do teste $t$ de Student, com nível de significância de 5\%. Resultados e Conclusão: Houve diferença significativa no peso do coração, na taxa de crescimento corporal, na área do ventrículo esquerdo e na espessura de parede do ventrículo direito entre os grupos. Não houve diferença estatística significativa na espessura da parede do ventrículo esquerdo e septo, mas observou-se tendência à diminuição. As áreas de miocitólise representaram $26,89 \%, 36,12 \%, 28,15 \%$ no ventrículo direito, septo e ventrículo esquerdo, respectivamente. A imunofluorescência mostrou que a distrofina foi a estrutura mais sensível ao dano provocado pelo isoproterenol, seguida pela perda completa da actina. A redução na expressão de $\gamma$-sarcoglicana, $\beta$-distroglicana, $\beta$-1 integrina e laminina, foram considerados como epifenômenos. A expressão de eNOS estava praticamente ausente nas áreas de miocitólise. A expressão aumentada de eNOS nos pequenos vasos ao redor das áreas de miocitólise sugere uma resposta compensatória à isquemia provocada pelo isoproterenol na tentativa de melhora do fluxo sangüíneo para as áreas de lesão. Foi observada alteração na permeabilidade sarcolemal nos cardiomiócitos dos animais tratados com isoproterenol com acúmulo de albumina no espaço intracelular. Observou-se que os cardiomiócitos e os macrófagos estavam constante e claramente marcados para apoptose nas áreas de miocitólise. Na ecocardiografia, os diâmetros sistólico e diastólico do ventrículo esquerdo foram significativemente maiores no grupo ISO em comparação com os controles. A fração de ejeção não foi diferente entre os grupos. O escore de mobilidade de parede mostrou hipocinesia ou acinesia nos segmentos apicais nos corações do grupo ISO. Essas mudanças, relacionadas à isquemia, podem explicar as graves alterações na integridade estrutural do sarcolema dos cardiomiócitos e a lesão induzida pelo isoproterenol. Mecanismos compensatórios no curto período de nosso experimento poderiam manter a função cardíaca normal apesar das graves alterações morfológicas encontradas.

Palavras-chave: isoproterenol; distrofina; complexo de glicoproteínas; miocitólise; isquemia. 


\section{ABSTRACT}

CAMPOS EC. Isoproterenol induces primary loss of dystrophin: correlation with myocardial injury. 2008. 90f. Dissertation (Master Science Degree). Department of Pathology - School of Medicine of Ribeirão Preto - University of São Paulo, 2008.

This study tested the hypothesis that the dystrophin-glycoprotein complex that confers structural stability in cardiomyocytes was affected in the isoproterenol-induced myocardial ischemia. Materials and Methods: Male Wistar rats were divided in control group (SAL), injected subcutaneously with physiological saline, and isoproterenol-treated group (ISO), injected with isoproterenol $(85 \mathrm{mg} / \mathrm{Kg})$ diluted in distilled water, in two consecutive days, separated by a $24-$ hour interval. These rats were killed 24 hours after the second injection of isoproterenol or physiological saline. The hearts were rapidly removed, rinsed in ice-cold $0.9 \%$ saline solution, weighed, and fixed as a whole in phosphate-buffered for 24 hours at $4{ }^{\circ} \mathrm{C}$. For morphometric analysis, the hearts cut into two fragments by a midventricular coronal section and embedded in paraffin. The absolute thicknesses of the septum and left and right ventricular walls and the areas of each ventricular chamber were measured. The hearts for Historesin embedding were frontally cut into anterior and posterior halves for analysis of myocytolytic areas. Hearts frontally cut were frozen for immunofluorescence study using primary antibodies against dystrophin, $\beta-1$ integrin, $\alpha$ sarcomeric actin, $\gamma$-sarcoglycan, $\beta$-dystroglycan, merosin laminin, albumin, CD68, CD45, CD4 e eNOS. The occurrence of apoptotic cells was evaluated by TUNEL method. The cardiac function, LV dimensions and wall motion segmented score were analyzed by echocardiography. For analysis of differences between the two groups the Student's $t$-test was performed and the level of significance of 5\% was chosen to denote difference between means. Results and Conclusion: There was significant difference in the heart weight, in the heart ratio, in the LV area and right ventricular (RV) thicknesses between the two groups. No statistical difference was observed in the thicknesses of the free wall of the LV and septum, although tended to be lower in isoproterenoltreated myocardium. The percentage of myocytolysis in the LV, septum, and RV with myocytolysis in isoproterenol treated rats was: $26.89 \%, 36.12 \%, 28.15 \%$, respectively. Immunofluorescence demonstrated that loss of dystrophin was the primary event in the myocytolytic process. Decreased expression of $\beta$-dystroglycan, $\gamma$-sarcoglycan, $\beta-1$ integrin and laminin occurred, appearing as epiphenomena. The eNOS expression was almost completely absent in the myocytolytic foci. eNOS expression was enhanced in blood vessels of cardiomyocytes through the entire myocardium of rats given isoproterenol. This is likely a compensatory response to the ischemic insult elicited by isoproterenol administration. In the myocytolytic foci a positive reaction for apoptosis was constantly and clearly noted in cardiomyocytes and macrophages. The echocardiography showed that diastolic and systolic LV dimensions in ISO-group were significantly higher in comparison with control group. The ejection fraction was not different between groups. The wall motion segmented score showed hypokinesis or akinesis in the apical segments in the hearts of ISO-group as compared with controls. These changes, related to ischemic injury, can explain the severe alterations in the structural integrity of the sarcolemma of cardiomyocytes and hence severe and irreversible injury induced by isoproterenol. Compensatory mechanisms in the short time of our experiment could maintain the normal cardiac function in spite of severe myocardial morphological changes.

Keywords: isoproterenol, dystrophin dystrophin-glycoprotein complex; myocytolysis; ischemia. 


\section{SUMÁRIO}

1 INTRODUÇÃO 15

2 OBJETIVO 20

3 MATERIAIS E MÉTODOS 21

3.1 CONSIDERAÇÕES GERAIS 21

3.2. DELINEAMENTO EXPERIMENTAL 21

3.3 MORTE DOS ANIMAIS E COLETA DO MATERIAL 22

3.4 MICROSCOPIA ÓPTICA CONVENCIONAL 22

3.5 MICROSCOPIA ÓPTICA DE ALTA RESOLUÇÃO 22

3.6 ANÁLISE DO CORAÇÃO E MORFOMETRIA 23

3.7 IMUNOFLUORESCENNCIA 23

3.8 AVALIAÇÃO DA APOPTOSE 25

3.9 ECOCARDIOGRAFIA 26

3.10 ANÁLISE ESTATÍSTICA 28

4 RESULTADOS 29

4.1 ESTADO GERAL DOS ANIMAIS 29

4.2 MORFOMETRIA 29

4.3 MICROSCOPIA ÓPTICA CONVENCIONAL E DE ALTA RESOLUÇÃO 32

4.4 IMUNOFLUORESCÊNCIA 35

4.5 AVALIAÇÃO DA APOPTOSE 45

$\begin{array}{ll}4.6 \text { ECOCARDIOGRAFIA } & 47\end{array}$

5 DISCUSSÃO

6 CONCLUSÃO

$\begin{array}{ll}\text { REFERÊNCIAS } & 63\end{array}$

$\begin{array}{ll}\text { ANEXOS } & 70\end{array}$ 


\section{INTRODUÇÃO}

Ao longo dos anos tem-se tentado estabelecer modelos animais de isquemia e infarto do miocárdio que apresentem analogia à doença humana. A administração de catecolaminas exógenas tem sido freqüentemente usada para indução de lesão cardíaca similar ao infarto do miocárdio em humanos. O uso do isoproterenol, uma catecolamina sintética estruturalmente relacionada à adrenalina, foi descrito incialmente por Rona et al. (1959). O isoproterenol atua exclusivamente em receptores $\beta$-adrenérgicos e é capaz de produzir necrose miocárdica, conhecida como lesão semelhante ao infarto (infarct-like lesion) em animais.

As lesões cardíacas estão geralmente localizadas no ápice cardíaco, predominantemente no ventrículo esquerdo e septo interventricular e, ocasionalmente, no ventrículo direito. Microscopicamente, têm sido caracterizadas por dilatação capilar, edema, presença de células inflamatórias, desintegração granular ou necrose hialina de miofibras e lise das miofibrilas (Rona et al., 1959; Chappel et al., 1959). A lise de miofibrilas, conhecida como miocitólise (Schlesinger \& Reiner, 1955) ou degeneração miofibrilar (Reinchenbach \& Benditt, 1970), é caracterizada principalmente pelo desaparecimento focal das células miocárdicas.

$\mathrm{O}$ isoproterenol possui ações inotrópica e cronotrópica positivas promovendo aumento do débito cardíaco, da freqüência cardíaca e da velocidade de ejeção. $\mathrm{O}$ aumento da freqüência cardíaca provoca incremento do trabalho com conseqüente aumento na demanda de oxigênio pelo músculo cardíaco (Gun \& Mady, 1999). Além disso, o aumento de trabalho imposto ao miocárdio também causa depleção das reservas de energia das células musculares cardíacas, o que ocasiona complexas mudanças bioquímicas e estruturais que levam à alterações na permeabilidade de membrana (Handforth, 1962; Rona, 1985). O mecanismo exato da lesão miocárdica provocada pelo isoproterenol, todavia, ainda não está totalmente esclarecido; mas um desequilíbrio entre oferta e demanda de oxigênio versus hipotensão nas coronárias e hiperatividade miocárdica, parece ser a melhor explicação para as mudanças morfológicas observadas no miocárdio na presença de vasculatura patente (Grimm et al., 1998). Outros mecanismos fisiopatogenéticos têm sido propostos para explicar as lesões miocárdicas 
produzidas pelo isoproterenol: (a) efeito cardiotóxico direto ao induzir alterações na permeabilidade de membrana (Milei \& Rapaport, 1976); (b) perda local de potássio com alterações do potencial de membrana (Rosenmann et al., 1964); (c) redução da perfusão no subendocárdio e consumo excessivo de oxigênio devido ao efeito inotrópico (Kahn et al., 1969); (d) aumento da mobilização de ácidos graxos, da peroxidação lipídica e da geração de radicais livres que aumentam a permeabilidade da membrana (Noronha-Dutra et al., 1982 e 1984; Singal et al., 1983; Mohan \& Bloom, 1999); (e) perda do acoplamento intracelular de alta energia (Milei et al., 1978); (f) desequilíbrio eletrolítico (Singal et al., 1981 e 1982) e (g) aumento do influxo de cálcio para o meio intracelular (Dhalla et al., 1996).

As mudanças bioquímicas e estruturais comprometem a integridade estrutural do sarcolema nos cardiomiócitos expostos ao isoproterenol (Yunge et al., 1989). A integridade do sarcolema é mantida pela presença das proteínas estruturais dos cardiomiócitos que compreendem: as proteínas do citoesqueleto celular (tubulina, desmina e actina), as proteínas do sistema contrátil (actina, miosina, tropomiosina e troponinas) e as proteínas do esqueleto sarcomérico (titina, $\alpha$-actinina, etc) (Kostin et al., 2000). Há ainda três grupos de proteínas estruturais que contribuem para a forma celular, resistência mecânica e transdução de sinal nos cardiomiócitos e permitem a interação entre o citoesqueleto intracelular, o sistema contrátil e a matriz extracelular conferindo estabilidade estrutural à membrana do cardiomiócito (Kostin et al., 1998; Hein et al., 2000; Kostin, 2000; Xi et al., 2000): a distrofina e o complexo de proteínas associadas à ela (distroglicanas, sarcoglicanas, sarcospana, distrobrevina e sintrofinas), a ligação talina-vinculina-integrina e a ligação espectrina-face interna da membrana (Figura 1).

A distrofina é um dos principais componentes do complexo de glicoproteínas e se localiza logo abaixo do sarcolema, co-localizada com a $\beta$-espectrina e a vinculina. Desempenha um papel importante no estabelecimento de conexões entre o meio intracelular, o citoesqueleto da actina e/ou a estrutura sarcomérica e a membrana basal externa. Apresenta três funções básicas, como a estabilização da membrana durante ciclos de contração, a transdução de força e a organização de especializações da membrana (Towbin, 1998; Lapidos et al., 2004). A porção N-terminal da distrofina liga-se à actina e a porção C-terminal liga-se à proteína 
transmembrana $\beta$-distroglicana. Esta se conecta à $\alpha$-distroglicana, que por sua vez está ligada à matriz extracelular através da laminina (Winder, 2001; Ganote \& Armostrong, 2002). Além dessa interação com o meio intracelular, as distroglicanas participam também da organização da matriz extracelular (Henry \& Campbell, 1996). As sarcoglicanas formam um subcomplexo de glicoproteínas transmembrana composto por seis subunidades $\alpha, \beta, \gamma, \varepsilon, \zeta$ e $\delta$ sarcoglicanas. A função das sarcoglicanas ainda não é bem conhecida, mas sabe-se que essas glicoproteínas estabilizam a interação entre as $\alpha$ e $\beta$-distroglicanas (Straub et al., 1998; Mcnally et al., 2003). A presença de outras proteínas na membrana celular, como as integrinas, também permite a ligação entre o citoesqueleto e a matriz extracelular (Kostin et al., 2000). As integrinas são proteínas transmembrana formadas pelas subunidades $\alpha$ e $\beta$, consideradas receptores de adesão celular para proteínas dentro da matriz extracelular (laminina, fibronectina, colágeno) e também estabelecem relação com a actina do citoesqueleto (Kostin et al., 1998; Delon \& Brown, 2007). As integrinas desempenham ainda papel na organização, diferenciação e migração celular (Ross, 2002) e na resistência à tensão gerada ao longo do sarcolema durante a contração celular (Van Der Flier \& Sonnenberg, 2001; Delon \& Brown, 2007). A laminina, considerada o maior componente da matriz extracelular, altamente expressa nos músculos cardíaco e esquelético, composta por duas isoformas $\alpha$ e $\beta$, mantém uma forte interação com a distrofina através do complexo das distroglicanas. Dessa forma, a comunicação entre os meios intra e extracelular é estabelecida (Mcnally et al., 2003).

A organização e interação entre as glicoproteínas são importantes para o entendimento dos mecanismos celulares envolvidos na disfunção mecânica presente nas cardiomiopatias (Stevenson et al., 1998; Xi et al., 2000). Diversos estudos em humanos e em modelos animais indicam que a perda da associação entre as estruturas do complexo de glicoproteínas associadas à distrofina e a laminina pode levar ao desenvolvimento de cardiomiopatia (Oliviéro et al., 2000; Lapidos et al., 2004; Heydemann \& Mcnally, 2007). A ausência de um ou mais componentes deste complexo causa degeneração muscular progressiva (Hack et al., 2000) e implica na ruptura da ligação física que ancora a actina ao citoesqueleto subsarcolemal e os sarcômeros ao sarcolema (Danialou et al., 2001), com conseqüente perda de função e morte celular (Lapidos et al., 2004). A perda de distrofina, por exemplo, é a causa da distrofia 
muscular de Duchenne e está freqüentemente acompanhada por cardiomiopatia. Os cardiomiócitos que perdem a distrofina são mais vulneráveis ao estresse mecânico imposto sobre a célula, resultando na perda da integridade do sarcolema e degeneração miofibrilar (miocitólise), com conseqüente disfunção contrátil (Danialou et al., 2001; Heydemann \& Mcnally, 2007). Ainda, foi demonstrado o papel das glicoproteínas associadas à distrofina na lesão por isquemia-reperfusão no miocárdio de cães (Rodríguez et al., 2005), em hamsters deficientes de sarcoglicana (Straub et al., 1998) e em biópsias miocárdicas de humanos com cardiomiopatia dilatada (Vatta et al., 2002). 


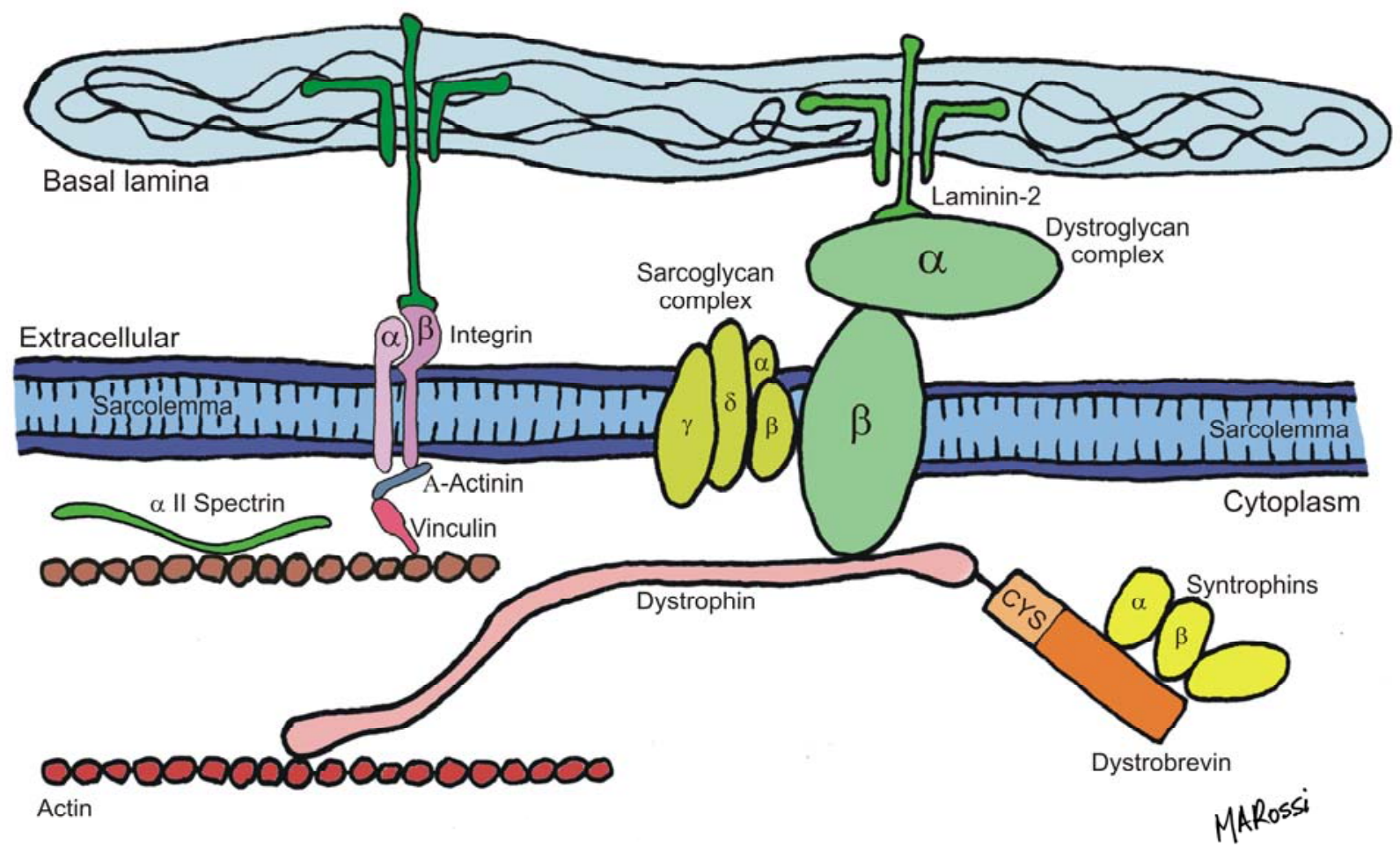

Figura 1: Esquema do complexo de glicoproteínas associadas à distrofina. 


\section{OBJETIVO}

O presente estudo foi proposto para avaliar a hipótese de que o isoproterenol afeta a estabilidade do sarcolema através de alterações nos componentes do complexo de glicoproteínas associadas à distrofina, que teria relação com a injúria miocárdica. 


\section{MATERIAIS E MÉTODOS}

\subsection{CONSIDERAÇÕES GERAIS}

Foram utilizados ratos Wistar, machos, com peso de 140 a 170 gramas, provenientes do Biotério Central da FMRP/USP. Os animais foram alocados em gaiolas construídas com polipropileno e tampas de aço inoxidável perfurado, lavadas três vezes por semana. Os animais foram alimentados com dieta sólida de laboratório e água ad libitum. A composição aproximada de dieta normalmente comercializada é (g/100g): proteína 21,0; gordura 3,5; carboidratos 60,0; sais 5,3; complexo vitamínico 2,0 e cinzas (dados fornecidos pelo produtor). Esta dieta provê aproximadamente 3,5 Kcal/g. O presente projeto de pesquisa foi aprovado pela Comissão de Ética no Uso de Animais (CEUA) da Universidade de São Paulo Campus Ribeirão Preto com Protocolo n 06.1.480.53.0 em 11/09/2006 (Anexo A).

\subsection{DELINEAMENTO EXPERIMENTAL}

Injeção de Isoproterenol

Os animais foram divididos em dois grupos: controle (SAL) e tratado com isoproterenol (ISO). Os animais do grupo tratado com isoproterenol receberam duas injeções subcutâneas de cloridrato de DL-Isoproterenol (Sigma Co., St. Louis, MO, EUA), separadas por um intervalo de 24 horas, na dose de $85 \mathrm{mg} / \mathrm{kg}$. Com esta dosagem, lesões cardíacas importantes podem ser observadas sem estarem associadas com alterações significativas em outros órgãos, exceto a congestão dos pulmões e das vísceras abdominais (Rona et al., 1959). A solução de isoproterenol foi preparada com água destilada imediatamente antes de ser administrada. Os animais do grupo controle receberam duas injeções subcutâneas de solução salina com intervalo de 24 horas entre as mesmas. O volume de salina e de solução de isoproterenol injetado para cada animal foi de $1 \mathrm{ml}$. 


\subsection{MORTE DOS ANIMAIS E COLETA DO MATERIAL}

Após 24 horas da segunda injeção, os animais foram pesados e anestesiados através de inalação do vapor de éter etílico (Mallinckrodt Baker, S.A., Xalostoc, Edo. de Mex., México). A cavidade torácica foi aberta, expondo o coração ainda pulsando. Os corações foram rapidamente excisados, lavados com solução gelada $\left(4^{\circ} \mathrm{C}\right)$ de $\mathrm{NaCl}$ à $0,9 \%$ (Anexo $\left.\mathrm{B}\right)$, secos em papel filtro, pesados em balança de precisão (Denver Instrument Company, Arcada, CO, EUA) e fixados.

\subsection{MICROSCOPIA ÓPTICA CONVENCIONAL}

Os corações inteiros foram fixados por imersão em formol a 3,7\% em PBS (Anexo C) e mantidas em geladeira à $4^{\circ} \mathrm{C}$ por uma noite. Após, os ventrículos foram cortados transversalmente na porção medioventricular, equidistante entre o ápice e a base, para realização da morfometria. As amostras foram desidratadas em soluções crescentes de álcool 80\%, 95\% (30 minutos cada) e 100\% (4 trocas de 1 hora cada). Após o último álcool, as amostras foram clarificadas em xilol ( 3 banhos de 30 minutos cada), dois banhos de parafina ( 2 horas cada) e incluídas em parafina. Cada bloco de parafina foi cortado em secções de $5 \mu \mathrm{m}$ de espessura e, posteriormente, corados com hematoxilina e eosina (Anexo C). Cortes frontais também foram obtidos, processados e incluídos em parafina para análise histopatológica.

\subsection{MICROSCOPIA ÓPTICA DE ALTA RESOLUÇÃO}

Após $24 \mathrm{~h}$ de fixação em formol a 3,7\% em PBS $\left(4^{\circ} \mathrm{C}\right)$, os corações foram cortados frontalmente em metades anterior e posterior, equidistante entre o ápice e a base. Esses corações foram processados em soluções crescentes de álcool 70\%, 95\% (3 trocas de 15 minutos cada) e 100\% (3 trocas de 1 hora cada), passados pela solução pré-infiltradora (24 horas), solução infiltradora (24 horas) e incluídos em resina e colocados em suportes apropriados (Historesin ${ }^{\circledR}$, Leica Instruments $\mathrm{GmbH}$, Heidelberg, Alemanha) (Anexo B). O material foi deixado pelo menos 24 horas em estufa a $60^{\circ} \mathrm{C}$ para endurecimento da resina. Cortes de 2,5 $\mu \mathrm{m}$ foram obtidos em micrótomo Sorvall JB4-A (DuPont Company, Newtown, CT, EUA), estirados em banho-maria à temperatura ambiente, colocados em lâmina de vidro e 
secos em platina aquecida a uma temperatura de $55-60^{\circ} \mathrm{C}$ por aproximadamente 24 horas. Logo após, os cortes foram corados com azul de toluidina (Anexo C). Para análise das áreas de miocitólise foi utilizado o programa Leica Qwin Software V 3.2.0 (Leica Imaging Systems Ltd., Cambridge, Inglaterra) em conjunto com um microscópio óptico Leica DMR (Leica Mycrosystems Wetzlar GmbH, Wetzlar, Inglaterra), videocâmera (Leica DC300F, Leica Mycrosysrems AG, Heerbrugg, Suíça) e um computador on-line. Os valores referentes às áreas de miocitólise foram obtidos em relação à área total dos ventrículos esquerdo e direito e do septo e expressos em porcentagem.

\subsection{ANÁLISE DO CORAÇÃO E MORFOMETRIA}

O índice de peso do coração $(\mathrm{g} / \mathrm{kg})$ foi calculado dividindo-se o peso do coração pelo peso corporal do animal. A taxa de crescimento (g/dia) foi calculada subtraindo-se o peso final do animal do peso inicial. Esse valor foi dividido pelo número de dias do experimento. A análise morfométrica do coração foi realizada através do programa Image J (desenvolvido pelo U.S. National Institute of Health e disponível na internet http://rsb.info.nih.gov/ij/download.html). Foram utilizados os corações cortados transversalmente e incluídos em parafina e corados com hematoxilina e eosina. Foram avaliadas as áreas dos ventrículos direito e esquerdo e a espessura da parede livre dos ventrículos esquerdo e direito e do septo.

\subsection{IMUNOFLUORESCÊNCIA}

Os corações foram rapidamente excisados, lavados com solução gelada $\left(4^{\circ} \mathrm{C}\right)$ de $\mathrm{NaCl}$ à 0,9\%, secos em papel filtro, pesados em balança de precisão (Denver Instrument), seccionados frontalmente em metades anterior e posterior, equidistante entre o ápice e a base. Esses corações foram colocados em meio de criopreservação Tissue-Tek (Triangle Biomedical Sciences, Durham, NC, EUA) e imediatamente congelados em isopentano 99\% (Vetec

Química, Rio de Janeiro, RJ) resfriado em recipiente contendo nitrogênio líquido. As amostras foram armazenadas à $-80^{\circ} \mathrm{C}$ para estudo em imunofluorescência. Cortes de $5 \mu \mathrm{m}$ de espessura foram obtidos no criostato Leica CM 1850 (Leica Instruments Nussloch GmbH, Nussloch, Alemanha), transferidos para lâminas silanizadas e fixados em acetona gelada por 10 minutos. 
Depois de fixados, e secas em temperatura ambiente, as lâminas foram lavadas com PBS (3 vezes de 10 minutos) (Anexo B) e colocadas em Triton 0,5\% em PBS durante 15 minutos. As lâminas foram lavadas novamente com PBS (3 vezes de 10 minutos), e posteriormente incubadas com soro normal de cavalo 1:50 (Vector Laboratories, Burlingame, CA, EUA) durante 30 minutos. Após, as lâminas foram incubadas com anticorpo primário diluído em BSA $1 \%$ e deixadas overnight à $4^{\circ} \mathrm{C}$. Foram utilizados anticorpos primários contra: distrofina (anticorpo policlonal de coelho anti-distrofina, Santa Cruz Biotechnology, Santa Cruz, CA, EUA, diluição 1:100 e 1:50), $\beta$-1 integrina (anticorpo monoclonal de camundongo anti- $\beta-1$ integrina, Chemicon International Inc., Billerica, MA, EUA, diluição 1:200), albumina (anticorpo monoclonal de camundongo anti-albumina conjugada com FITC, Bethyl Laboratories Inc., Montgomey, Texas, EUA, diluição 1:600), $\alpha$ - actina sarcomérica (anticorpo monoclonal de camundongo anti- $\alpha$-actina sarcomérica, clone 5C5, Sigma Co., St. Louis, MO, EUA, diluição 1:400), $\gamma$-sarcoglicana (anticorpo monoclonal de camundongo anti- $\gamma$ sarcoglicana, Vector Laboratories, Burlingame, CA, EUA, diluição 1:400), $\beta$-distroglicana (anticorpo monoclonal de camundongo anti- $\beta$-distroglicana, Vector Laboratories, diluição 1:400), merosina laminina $\alpha-2$ (anticorpo monoclonal de camundongo anti- merosina laminina $\alpha-2$, Vector Laboratories, diluição 1:100), CD68 (anticorpo monoclonal de rato anti-CD68, Serotec Ltd., Kidlington, OX, Inglaterra, diluição 1:200), óxido nítrico sintase endotelial, eNOS (anticorpo policlonal de coelho anti-eNOS, Labvision Corp, Freemont, CA, EUA, diluição 1:150), CD4 (anticorpo monoclonal de camundongo anti-CD4, BioLegend, San Diego, CA, EUA, diluição 1:100) e CD45 (Antígeno comum leucocitário, Ly-5; anticorpo monoclonal de camundongo anti-CD45, BD Biosciences, San Jose, CA, EUA, diluição 1:100). As lâminas para as reações com anticorpos primários anti- $\gamma$-sarcoglicana, $\beta$-distroglicana e $\beta-1$ integrina não foram fixadas com acetona.

Após o anticorpo primário, as lâminas foram retiradas da geladeira até a temperatura estabilizar, lavadas com PBS (3 vezes de 10 minutos) e incubadas com anticorpo secundário. Foram utilizados como anticorpos secundários conjugados com fluoresceína: $\alpha$-mouseIgG/FITC, $\alpha$-mouse-IgG/AMCA, $\alpha$-rabbit-IgG/Texas red (Vector Laboratories) 1:200 diluídos em HEPES 0,01 M, durante 1 hora em temperatura ambiente e posteriormente lavadas com 
PBS (3 vezes de 10 minutos). Para marcação de actina foi utilizada faloidina (Molecular Probes, Eugene, OR, EUA) 1:200 diluída em BSA 0,1\%. As lâminas foram deixadas na estufa a $37^{\circ} \mathrm{C}$ por 30 minutos e lavadas novamente com PBS (3 vezes de 10 minutos). A marcação nuclear foi feita com 4',6-diamidino-2-phenylindole dihidrochloryde (DAPI, Molecular Probes) por 3 minutos. Posteriormente, as lâminas foram lavadas com PBS (3 vezes de 10 minutos) e montadas com Prolong ${ }^{\circledR}$ (Invitrogen, Molecular Probes). As lâminas com marcação para merosina laminina $\alpha-2$ foram fixadas em paraformoldeído $2 \%$ por 1 minuto após anticorpo secundário, antes de serem montadas.

As lâminas foram analisadas através do programa Leica Qwin Software V 3.2.0 (Leica Imaging Systems Ltd., Cambridge, Inglaterra) em conjunto com um microscópio de fluorescência Leica DMR (Leica Microsystems Wetzlar GmbH, Wetzlar, Alemanha), videocâmera (Leica DC300F, Leica Mycrosysrems AG, Heerbrugg, Suíça) e um computador on-line.

\subsection{AVALIAÇÃO DA APOPTOSE}

A avaliação da apoptose no miocárdio dos animais controle e tratado com isoproterenol foi avaliada in situ utilizando-se o método do TUNEL (TdT-dUTP). Essa técnica detecta a fragmentação precoce do DNA, característica das células apoptóticas, através da incorporação de nucleotídeos biotinilados ao terminal 3'-OH do DNA fragmentado pela ação da enzima deoxinucleotidil transferase terminal (dUTP). Para realização da técnica foi utilizado um kit disponível comercialmente (Dead End Colorimetric TUNEL System, Promega Corporation, Madison, WI, EUA). Cortes de $5 \mu \mathrm{m}$ foram obtidos de corações incluídos em parafina, transferidos para lâminas de vidro silanizadas, que posteriormente foram desparafinizadas em xilol, desidratadas em soluções crescentes de álcool $80 \%, 95 \%$ e $100 \%$ e lavadas em solução salina por 5 minutos. Os cortes foram tratados com Proteinase $\mathrm{K} 20 \mu \mathrm{g} / \mathrm{ml}$ (1:500), previamente diluída em água deionizada, durante 30 minutos em temperatura ambiente. As lâminas foram lavadas com PBS e colocadas no tampão de equilíbrio ( $200 \mathrm{mM}$ de cacodilato de potássio, $25 \mathrm{mM}$ Tris-HCl, $\mathrm{pH}$ 6,6, 0,2 mM DTT -Dithiothreitol, 2,5 mM cloridrato de cobalto e $0,25 \mathrm{mg} / \mathrm{ml} \mathrm{BSA}$, contidos em 9,6 ml - especificações do frabricante) por 10 
minutos. Posteriormente, as secções foram incubadas com uma solução contendo: mistura de nucleotídeos biotinilados, tampão de equilíbrio e a enzima TdT (Deoxiribonucleotidyl Transferase Terminal). Para uma lâmina utilizamos $98 \mu$ de tampão de equilíbrio, $1 \mu 1$ de mix de nucleotídeos biotinilados e $1 \mu \mathrm{l}$ de TdT. Cada corte foi coberto com um recorte individual de plástico. Para incubação do anticorpo, as lâminas foram colocadas em câmara úmida na estufa à $37^{\circ} \mathrm{C}$ durante 2 horas. Após esse período, as lâminas foram retiradas da estufa e a solução de incubação foi aspirada e a reação bloqueada com 2X SSC (sodium-chloride sodium citrate buffer) por 15 minutos. As lâminas foram lavadas com PBS durante 5 minutos e subseqüentemente, utilizou-se o peróxido de hidrogênio $\left(\mathrm{H}_{2} \mathrm{O}_{2}\right)$ a $0,3 \%$ por 5 minutos para o bloqueio da peroxidase endógena. Após o bloqueio, as lâminas foram lavadas com PBS e incubadas com estreptoavidina HRP (streptoavidin horseradish peroxidase, 1:500), diluída em PBS, durante 30 minutos. As lâminas foram lavadas novamente com PBS durante 5 minutos e coradas com o cromógeno diaminobenzidina (DAB). A inserção dos nucleotídeos é revelada pela reação da peroxidase com a diaminobenzidina. Após a reação com DAB, as lâminas foram lavadas com PBS e depois com água destilada, contracoradas com Hematoxilina de Harris por 35 segundos e montadas com Permount ${ }^{\circledR}$ (Fischer Scientific, Pittsburgh, PA, EUA)

\subsection{ECOCARDIOGRAFIA}

Para análise da anatomia e da função cardíaca, foram avaliados os parâmetros ecocardiográficos dos animais dos grupos controle e experimental. Por causa das limitações de acurácia do transdutor do equipamento de ecocardiografia em nossa instituição e do curto período de experimento, foram utilizados animais com peso superior a $260 \mathrm{~g}$ e duas doses diferentes de isoproterenol, 85 e $150 \mathrm{mg} / \mathrm{kg}$. Os animais foram anestesiados com ketamina (Ketamina 10\%, Agener União Química Farmacêutica Nacional S/A, Embu-Guaçu, SP, Brasil, $74 \mathrm{mg} / \mathrm{Kg}$ ) e xilazina (Dopaser, Laboratórios Calier, SA, Barcelona, Espanha, 8 $\mathrm{mg} / \mathrm{Kg}$ ) administrados por via intraperitoneal, o que permitiu ao animal manter a respiração espontânea durante o exame. Após anestesia, foi realizada a tricotomia da região anterior do tórax. Os animais foram posicionados em decúbito lateral esquerdo para melhor análise da função global do ventrículo esquerdo. Foi utilizado o aparelho de ecocardiografia 
bidimendional Sonos HP 5500 (Philips, Andover, MA, EUA), com transdutor pediátrico com freqüência de $12 \mathrm{MHz}$.

Foram obtidas imagens bidimensionais e no modo-M dos eixos paraesternais longo e curto, visão apical e das quatro câmaras cardíacas, para serem gravadas em fita de vídeo. As melhores imagens foram usadas para avaliação off-line da função ventricular. A realização do exame e das medidas foi feita sempre pelo mesmo observador. A partir da projeção paraesternal do eixo curto do ventrículo esquerdo em nível de músculos papilares, foi usado o modo-M para quantificação das dimensões da cavidade do ventrículo esquerdo em diástole (DDVE) e sístole (DSVE), todos expressos em centímetros. Os valores referentes aos diâmetros da cavidade ventricular esquerda em sístole e em diástole foram utilizados para estimativa da função sistólica do ventrículo esquerdo através da fração de encurtamento do ventrículo esquerdo (Delta D). A fração de ejeção (FE) foi estimada pelo modo de Teicholtz e expressa em porcentagem. Todos os valores expressos representam a média de três valores consecutivos obtidos para cada animal.

A avaliação da mobilidade de parede foi realizada em 16 segmentos (4 na região apical, 6 na região média e 6 na região basal), baseados na visão de três eixos curtos do ventrículo esquerdo. Um escore de mobilidade foi utilizado para graduar o comprometimento da parede ventricular esquerda sendo, 1 para mobilidade normal, 2 para hipocinesia, 3 para acinesia, 4 para discinesia e 5 para aneurismático, de acordo com as diretrizes da Sociedade Americana de Ecocardiografia (Schiller et al., 1989). 
Abaixo estão descritas as fórmulas que o aparelho de ecocardiografia utiliza para calcular os valores do Delta $\mathrm{D}$ e da fração de ejeção do ventrículo esquerdo.

a) Delta D (\%) = (DDVE - DSVE / DDVE $)$ x 100

b) FE (\%) = Volume diastólico - Volume Sistólico / Volume diastólico

c) Volume diastólico $=\operatorname{DDVE}^{3} \times(7 / 2,4+$ DDVE $)$

d) Volume sistólico $=\operatorname{DSVE}^{3} \times(7 / 2,4+$ DDVE $)$

\subsection{ANÁLISE ESTATÍSTICA}

Os dados obtidos foram analisados utilizando-se o programa estatístico GraphPad Prism 4 (Graph Pad Software In., San Diego, California, EUA). Foi aplicado o teste de KolmogorovSmirnov para verificar se os dados apresentam distribuição normal. O teste $t$ de Student foi utilizado para comparação entre duas variáveis com distribuição normal. Os dados são apresentados como média \pm erro padrão da média. O teste não paramétrico de Kruskal-Wallis, seguido pelo pós-teste de Dunn's, foi usado para determinar a diferença entre as médias dos escores estimados para cada região do ventrículo esquerdo dos animais tratados com isoproterenol, 85 ou $150 \mathrm{mg} / \mathrm{kg}$ em comparação com os valores correspondentes dos animais controle. Um nível de significância de $5 \%$ foi escolhido para mostrar a diferença entre as médias. 


\section{RESULTADOS}

\subsection{ESTADO GERAL DOS ANIMAIS}

Dos animais utilizados no estudo, 7,69\% morreu antes do final do experimento, e este material foi desconsiderado. Similarmente, a taxa de mortalidade de $10 \%$ foi observada quando esta dose foi administrada em ratos com peso médio de $260 \mathrm{~g}$ (Rona et al., 1959). Os animais que receberam isoproterenol, um bem conhecido mediador do estresse comportamental, apresentaram sintomas característicos após a injeção, tais como posturas incomuns, respiração difícil e perda de apetite. Não foi observado exsudato nas narinas ou edema susbcutâneo. O peso corporal inicial dos animais do grupo controle variou de 143 a 167 g (média de 156,1 g) e, dos animais do grupo tratado com isoproterenol, o peso corporal inicial variou de $145 \mathrm{a} 169 \mathrm{~g}$ (média de 159,1 g). O peso corporal final dos animais do grupo controle variou de 161 a $190 \mathrm{~g}$ (média de $175 \mathrm{~g}$ ) e, dos animais tratados com isoproterenol, o peso corporal final variou de 148 a $192 \mathrm{~g}$ (média de 169,2 g). A tabela 1 mostra a média inicial e final do peso corporal, a taxa de crescimento corporal (g/dia/rato), o peso do coração e o índice de peso do coração $(\mathrm{g} / \mathrm{kg}$ ). Como conseqüência da perda de apetite, um retardo de $4 \%$ no ganho de peso corporal foi observado nos animais do grupo tratado com isoproterenol $(169,2 \pm 1,97 \mathrm{~g})$ quando comparados com os controles $(175,0 \pm 1,51 \mathrm{~g})$. Os valores referentes à taxa de crescimento corporal no grupo tratado com isoproterenol foram significantemente menores $(3,34 \pm 0,47 \mathrm{~g} / \mathrm{dia} / \mathrm{rato})$ em relação aos valores correspondentes ao grupo controle $(6,31 \pm 0,39 \mathrm{~g} / \mathrm{dia} /$ rato $)$, que representa uma redução de $88 \%$. O peso do coração dos animais do grupo tratado com isoproterenol $(0,89 \pm 0,01 \mathrm{mg})$ foi significantemente maior quando comparado aos animais do grupo controle $(0,74 \pm 0,01 \mathrm{mg})$, que representa um valor $21 \%$ superior. O índice de peso do coração foi $26 \%$ maior no grupo tratado com isoproterenol $(5,35 \pm 0,13 \mathrm{~g} / \mathrm{kg})$ quando comparado com o grupo controle $(4,23 \pm 0,09 \mathrm{~g} / \mathrm{kg})$. 
Tabela 1: Peso corporal, taxa de crescimento, peso do coração e índice de peso do coração dos animais dos grupos controle e tratado com isoproterenol.

\begin{tabular}{|c|c|c|c|c|c|}
\hline \multirow{2}{*}{ Grupos } & \multicolumn{2}{|c|}{ Peso corporal (g) } & \multirow{2}{*}{$\begin{array}{l}\text { Taxa } \\
\text { Crescimento } \\
\text { Corporal }\end{array}$} & \multirow{2}{*}{$\begin{array}{l}\text { Peso coração } \\
\text { (mg) }\end{array}$} & \multirow{2}{*}{$\begin{array}{l}\text { Índice de peso } \\
\text { do coração } \\
\text { (g/Kg) }\end{array}$} \\
\hline & Inicial & Final & & & \\
\hline Controle $(n=26)$ & $156,1 \pm 1,19$ & $175,0 \pm 1,51$ & $6,31 \pm 0,39$ & $0,74 \pm 0,01$ & $4,23 \pm 0,09$ \\
\hline ISO $(n=24)$ & $159,1 \pm 1,57$ & $169,2 \pm 1.97^{*}$ & $3,34 \pm 0,47^{* * *}$ & $0,89 \pm 0,01^{* * *}$ & $5,35 \pm 0,13^{* * *}$ \\
\hline
\end{tabular}

Os dados são a média \pm o erro padrão da média; ${ }^{*} \mathrm{p}<0.05 ; * * * \mathrm{p}<0.0001$. ISO, isoproterenol.

\subsection{MORFOMETRIA}

A análise morfométrica demonstrou que a área da câmara ventricular esquerda dos corações dos animais do grupo tratado com isoproterenol foi significantemente maior $\left(8,03 \pm 0,26 \mathrm{~mm}^{2}\right)$ quando comparada com os corações dos animais do grupo controle $\left(6,69 \pm 0,37 \mathrm{~mm}^{2}\right)$, que representa um valor $20 \%$ superior. Não foram encontradas diferenças significantes na área da câmara ventricular direita do grupo tratado com isoproterenol $\left(3,32 \pm 0,35 \mathrm{~mm}^{2}\right)$ quando comparado com os controles $\left(3,63 \pm 0,14 \mathrm{~mm}^{2}\right)$ (Figura 2). Os valores referentes à espessura da parede livre do ventrículo esquerdo e do septo interventricular foram similares em ambos os grupos, tratado com isoproterenol $(5,08 \pm 0,13$ e $6,01 \pm 0,22 \mathrm{~mm}$, respectivamente) e grupo controle $(5,20 \pm 0,21$ e 6,989 $\pm 0,38 \mathrm{~mm}$, respectivamente), embora esses valores apresentem tendência a diminuir nos animais do grupo tratado com isoproterenol. Ainda, a espessura da parede do ventrículo direito foi $26 \%$ menor no grupo tratado com isoproterenol $(0,85 \pm 0,04$

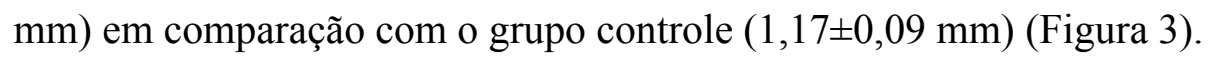


A

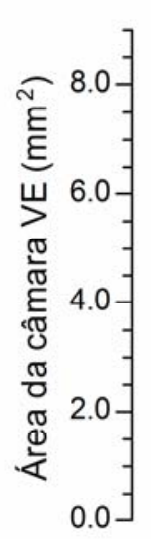

B

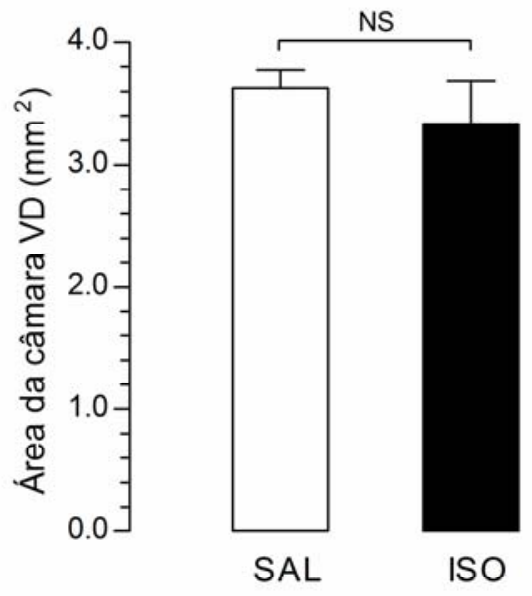

Figura 2: Área da câmara ventricular esquerda (A) e direita (B). Os dados são a média \pm erro padrão da média, $* p<0,05$. VE, ventrículo esquerdo; VD, ventrículo direito; NS, não significante.

A

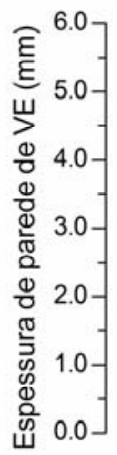

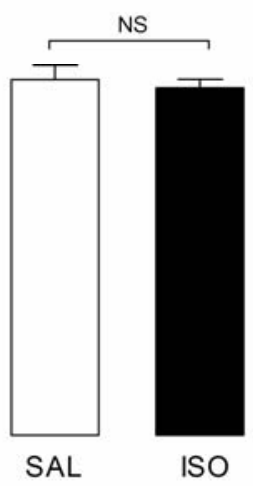

B

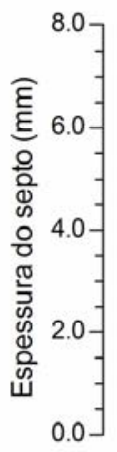

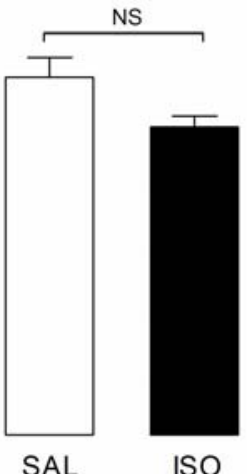

C
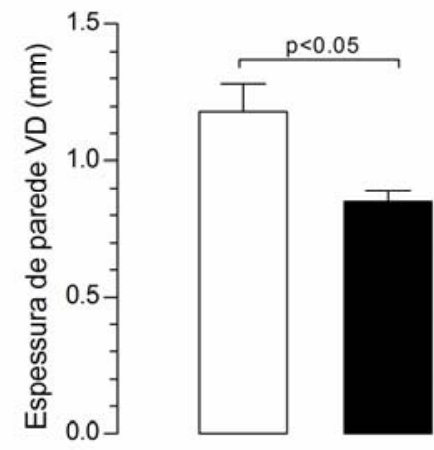

ISO

Figura 3: Espessura da parede do ventrículo esquerdo (A), septo (B) e ventrículo direito (C). Os dados são a média \pm erro padrão da média, ${ }^{*} \mathrm{p}<0,05$. VE, ventrículo esquerdo; VD, ventrículo direito; NS, não significante. 


\subsection{MICROSCOPIA ÓPTICA CONVENCIONAL E DE ALTA RESOLUÇÃO}

O coração dos animais de ambos os grupos foram incluídos em parafina e resina plástica e examinados no microscópio de luz transmitida. Não foram encontradas alterações patológicas no miocárdio dos animais do grupo controle. Os achados histológicos nos corações dos animais do grupo tratado com isoproterenol podem ser graduados de acordo com a gravidade das lesões: graduação 1) focos de miócitos que apresentam edema intracelular (tumefação) e degeneração vacuolar; graduação 2) focos de miocitólise, muitos deles coalescentes, observamos a lise de miofilamentos associada a presença de infiltrado inflamatório mononuclear; graduação 3) focos de cardiomiócitos remanescentes, espaços vazios e a presença de poucas células inflamatórias (Figuras 4,6).

O uso de material incluído em resina plástica e corado com azul de toluidina permitiu melhor resolução de detalhes estruturais para a realização das medidas das áreas de miocitólise. O miocárdio dos animais do grupo tratado com isoproterenol mostrou áreas focais e coalescentes de necrose miocitolítica predominantemente no ápice cardíaco, na região subendocárdica e subepicárdica do ventrículo esquerdo, no septo interventricular e na região subendocárdica do ventrículo direito. A distribuição média das áreas de necrose miocitolítica no miocárdio dos animais tratados com isoproterenol foi de $26,89 \pm 1,88 \%$ no ventrículo esquerdo, 36,12+2,7\% no septo e 28,15+3,96\% no ventrículo direito (Figura 5). 

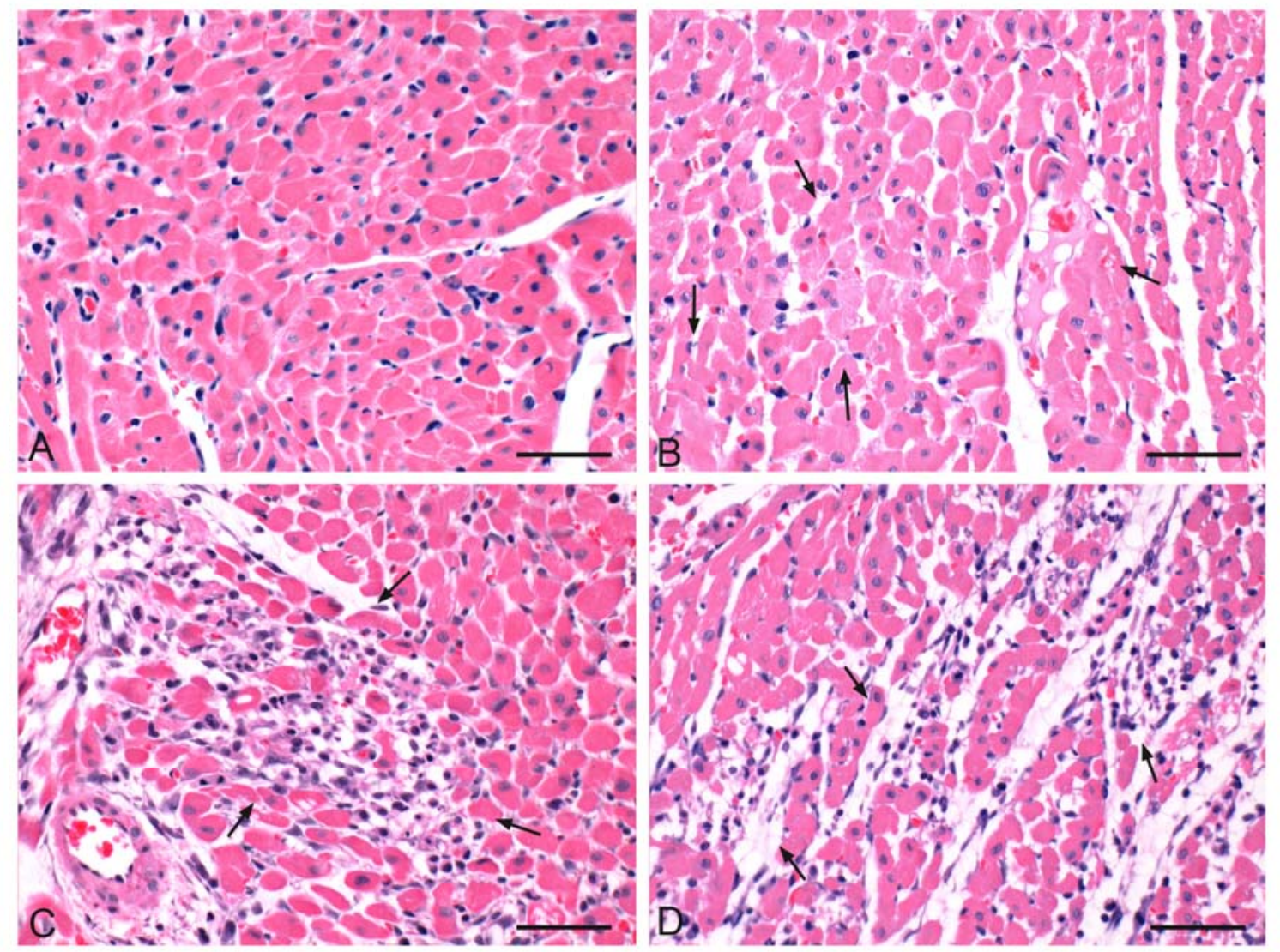

Figura 4: Microscopia óptica convencional. A) Grupo controle sem alterações patológicas. B) Lesão grau 1: edema intracelular e degeneração vacuolar (flechas). C) Lesão grau 2: lise de miofibras e infiltrado de células inflamatórias (flechas). D) Lesão grau 3: ausência de miofibras (flechas) e discreto infiltrado de células inflamatórias. Hematoxilina e eosina. Barra $=50 \mu \mathrm{m}$. 

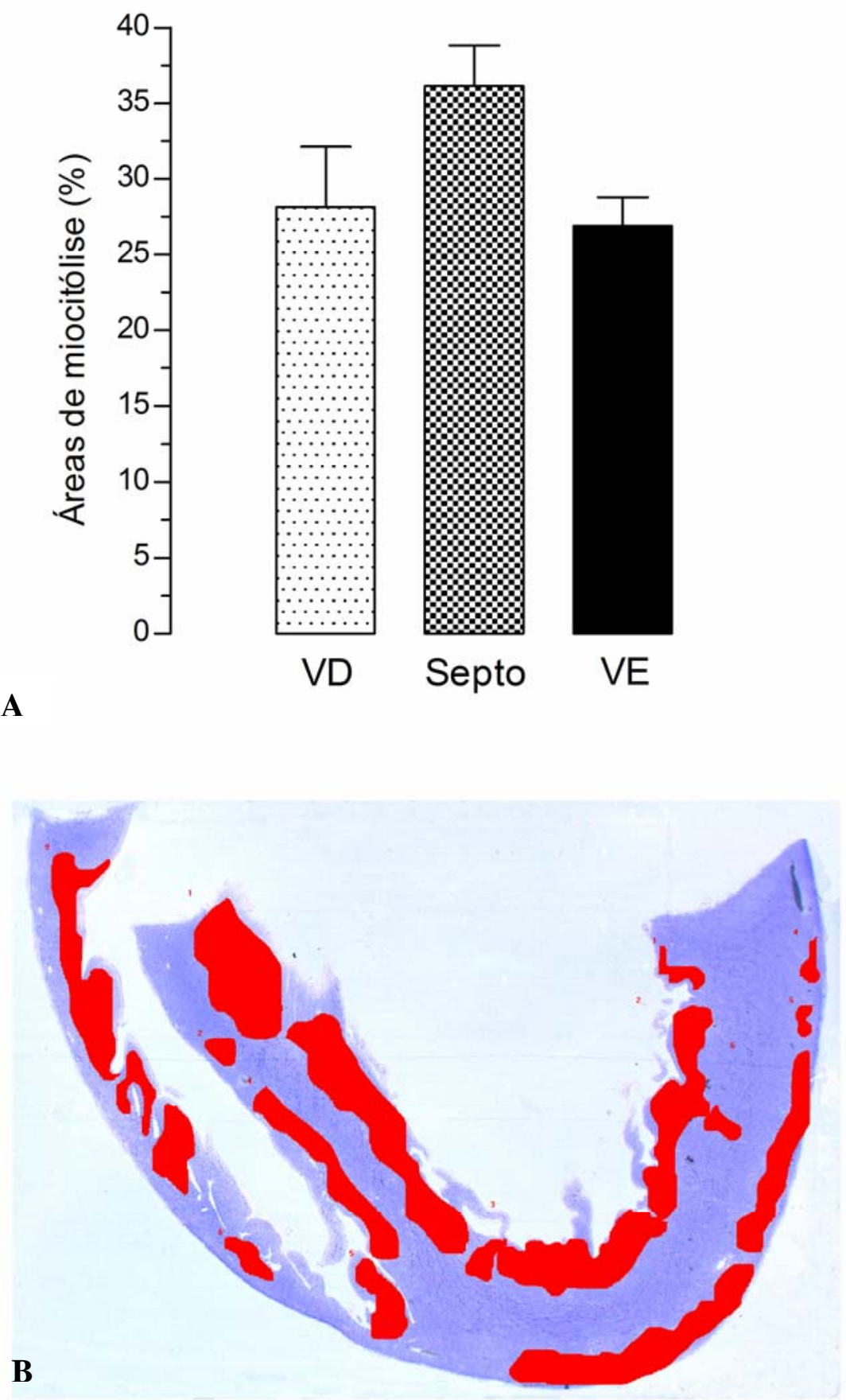

Figura 5: A) Representação gráfica e B) Microscopia óptica de alta resolução (aumento final 16x) referente às áreas de miocitólise. VD, ventrículo direito; VE, ventrículo esquerdo. 


\subsection{IMUNOFLUORESCÊNCIA}

$\mathrm{O}$ estudo do complexo de glicoproteínas associadas à distrofina através de imunofluorescência revelou que a distrofina está focalmente reduzida ou completamente ausente no miocárdio dos animais tratados com isoproterenol. Essa alteração na expressão da distrofina foi observada antes da perda da actina. Nas secções transversas, a dupla marcação para distrofina e actina sarcomérica indicou a presença de três padrões diferentes de marcação de acordo com a graduação da gravidade das lesões miocárdicas: a) corespondente a graduação 1 de lesão miocárdica, observa-se a perda da distrofina e presença da actina sarcomérica e ausência de células inflamatórias; b) corespondente a graduação 2 de lesão miocárdica, observa-se a perda da distrofina, graus variados de dissolução da actina sarcomérica associada a um grande número de células inflamatórias mononucleares e, c) corespondente a graduação 3 de lesão miocárdica, observa-se a perda de distrofina e actina sarcomérica associada à discreta presença de células inflamatórias mononucleares (Figura 6). O grupo controle mostrou padrão de distribuição uniforme para a distrofina e para actina sarcomérica. 


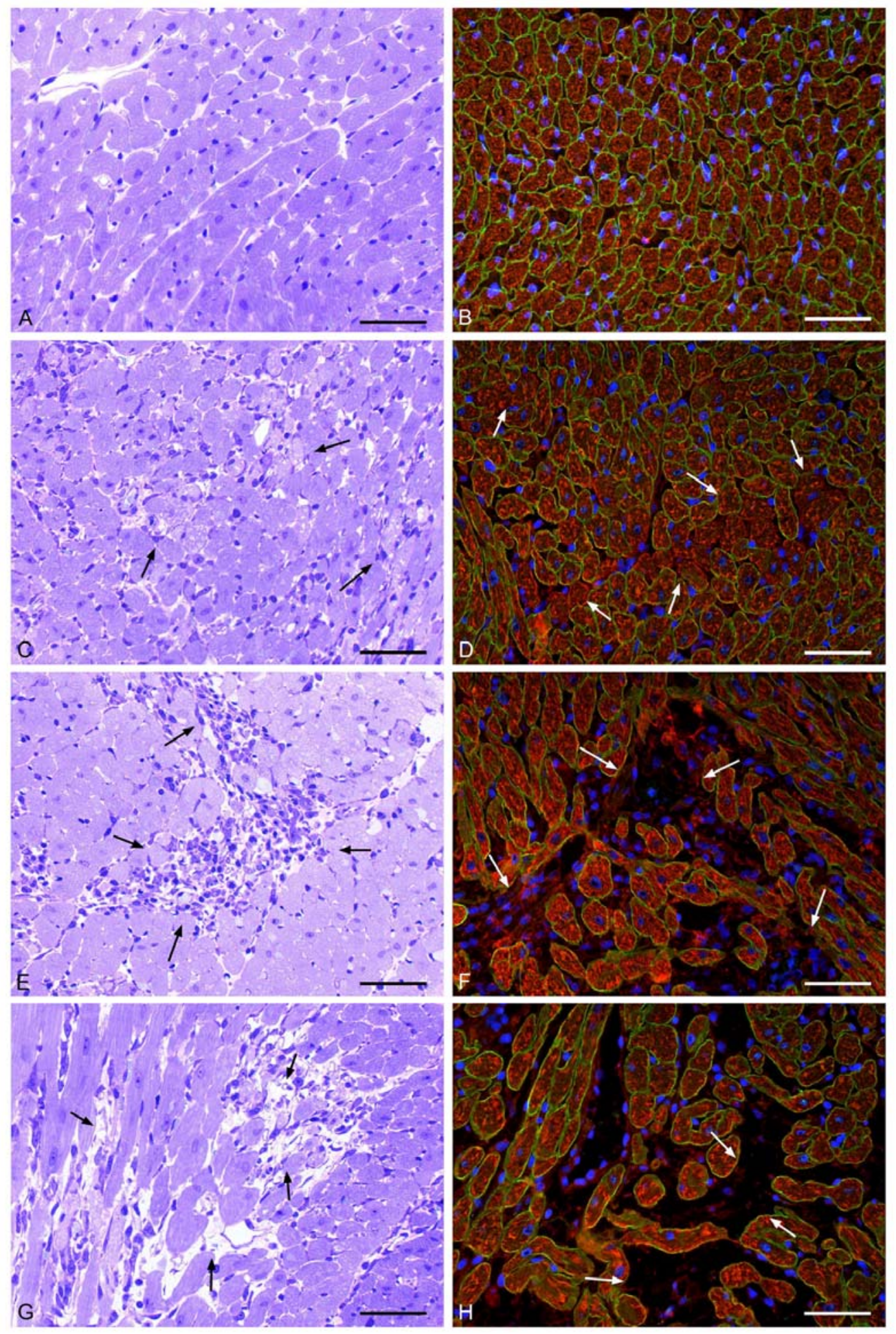

Figura 6: Microscopia óptica de alta resolução (A, C, E, G) e imunofluorescência (B,D,F,H) para distrofina (fluorescência verde) e actina sarcomérica (fluorescência vermelha). A e B) Grupo controle sem alterações patológicas. C-H) Grupo tratado com isoproterenol. C) Edema intracelular e degeneração vacuolar - lesão grau 1 (flechas). D) Perda de distrofina e concomitante presença de actina sarcomérica (flechas); E) Foco de miocitólise (flechas) associado a presença de infiltrado inflamatório mononuclear - lesão grau 2. F) Perda focal de distrofina e graus variados de dissolução da actina (flechas). A presença de infiltrado de células inflamatórias é revelada pela fluorescência azul (DAPI). G) Ausência de miofibras lisadas (flechas) e pequeno infiltrado inflamatório lesão grau 3. H) Perda focal de distrofina e concomitante de actina (flechas) e discreta presença de células inflamatórias revelada pela fluorescência azul (DAPI). Barra $=50 \mu \mathrm{m}$. 
A avaliação dos demais componentes do complexo de glicoproteínas, $\gamma$-sarcoglicana e $\beta$ distroglicana, da $\beta-1$ integrina, e da matriz extracelular merosina laminina $\alpha-2$, mostraram que estas estruturas desempenham papel secundário no processo de lise dos miócitos nas áreas de miocitólise. Observou-se que nos focos de miocitólise houve ligeira atenuação na intensidade de imunomarcação para $\gamma$-sarcoglicana, $\beta$-distroglicana, $\beta-1$ integrina e laminina $\alpha-2$, associada à perda completa da actina nesses mesmos focos. Subseqüentemente à lise dos miofilamentos, que corresponde a graduação 3 de lesão miocárdica, pôde-se observar que essas estruturas podem estar colapsadas associada à presença de poucas células inflamatórias na área de miocitólise (Figuras 7-10). Para distinguirmos exatamente a reduzida expressão dos components do complexo de glicoproteínas associadas à distrofina na mesma area, nós utilizamos a dupla marcação para distrofina e $\gamma$-sarcoglicana ou $\beta$-distroglicana ou $\beta-1$ integrina ou merosina laminina $\alpha-2$. Observamos que nas áreas de lesão miocárdica que correspondem ao grau 1, a perda da distrofina é claramente vista com a persistência dos elementos remanescentes do complexo de glicoproteínas e da merosina laminina $\alpha-2$, embora atenuados, enquanto que nas áreas de lesão correspondentes aos graus 2 e 3 , a perda da distrofina é claramente notada com a expressão atenuada ou com o colapso dos elementos remanascentes do complexo de glicoproteínas e da merosina laminina. No miocárdio dos animais do grupo controle não foi encontrado alterações patológicas. Na figura 11, a dupla marcação para distrofina e $\beta-1$ integrina ilustra claramente estes achados. 

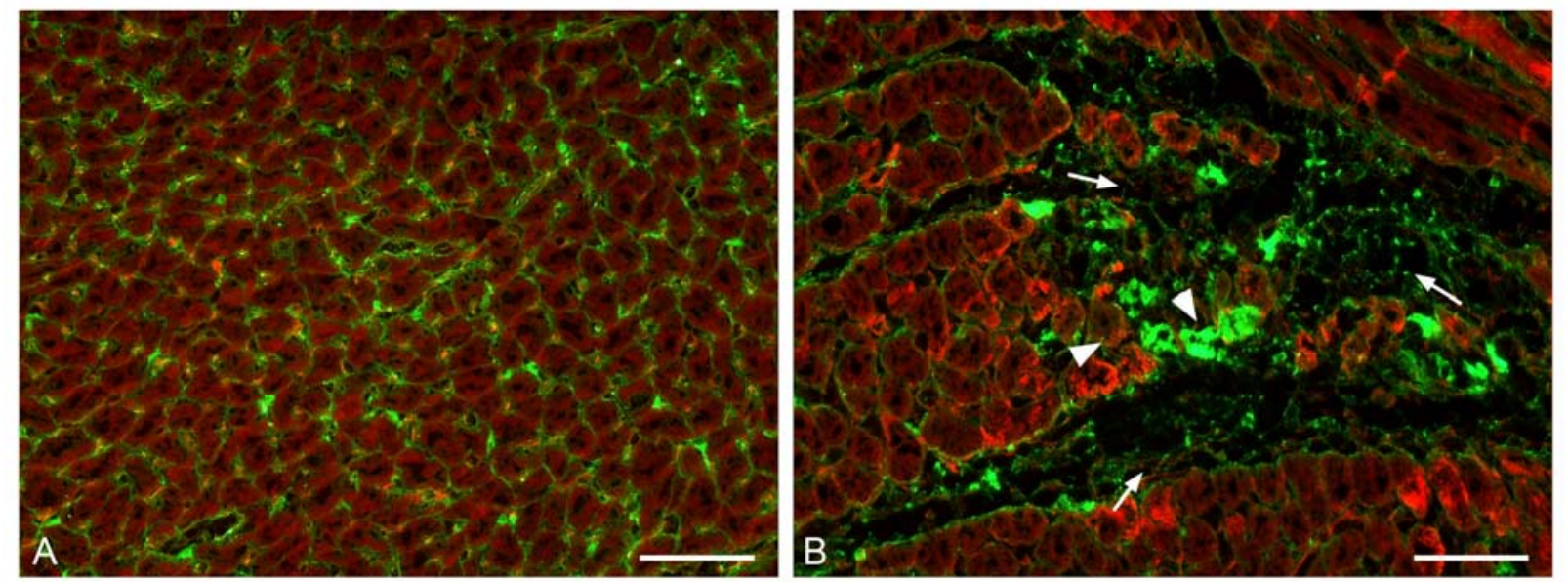

Figura 7: Imunofluorescência para $\gamma$-sarcoglicana (fluorescência verde) e actina (faloidina, fluorescência vermelha). A) Grupo controle: marcação uniforme de $\gamma$-sarcoglicana delineando o perfil externo dos miócitos; a actina marca todos os miócitos. B) Grupo tratado com isoproterenol: redução da marcação, mas persistência do perfil miocelular delineado pela $\gamma$-sarcoglicana (flechas) e áreas de colapso (cabeças das flechas), com perda de actina. Barra $=50 \mu \mathrm{m}$.
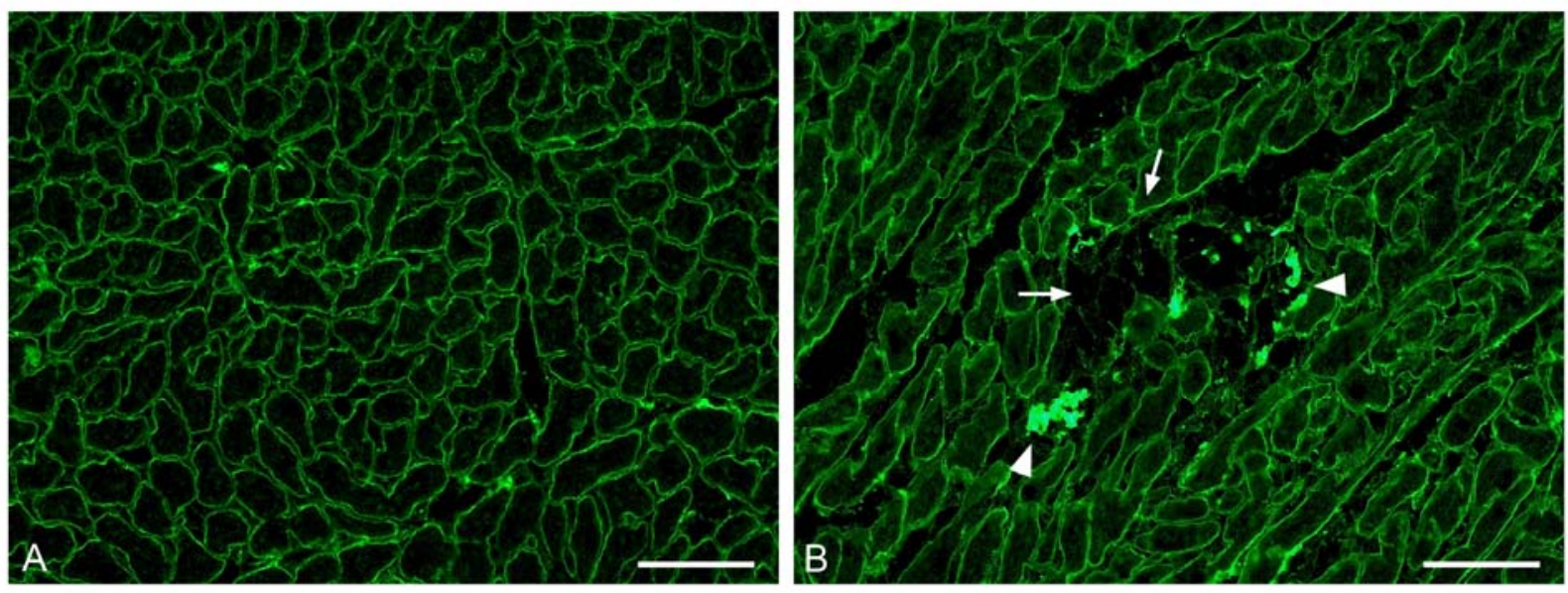

Figura 8: Imunofluorescência para $\beta$-distroglicana. A) Grupo controle: marcação uniforme da $\beta$-distroglicana delineando o perfil externo dos miócitos. B) Grupo tratado com isoproterenol: redução da marcação, mas persistência do perfil miocelular delineado pela $\beta$-distroglicana (flechas) e áreas de colapso (cabeças das flechas). Barra $=50 \mu \mathrm{m}$. 

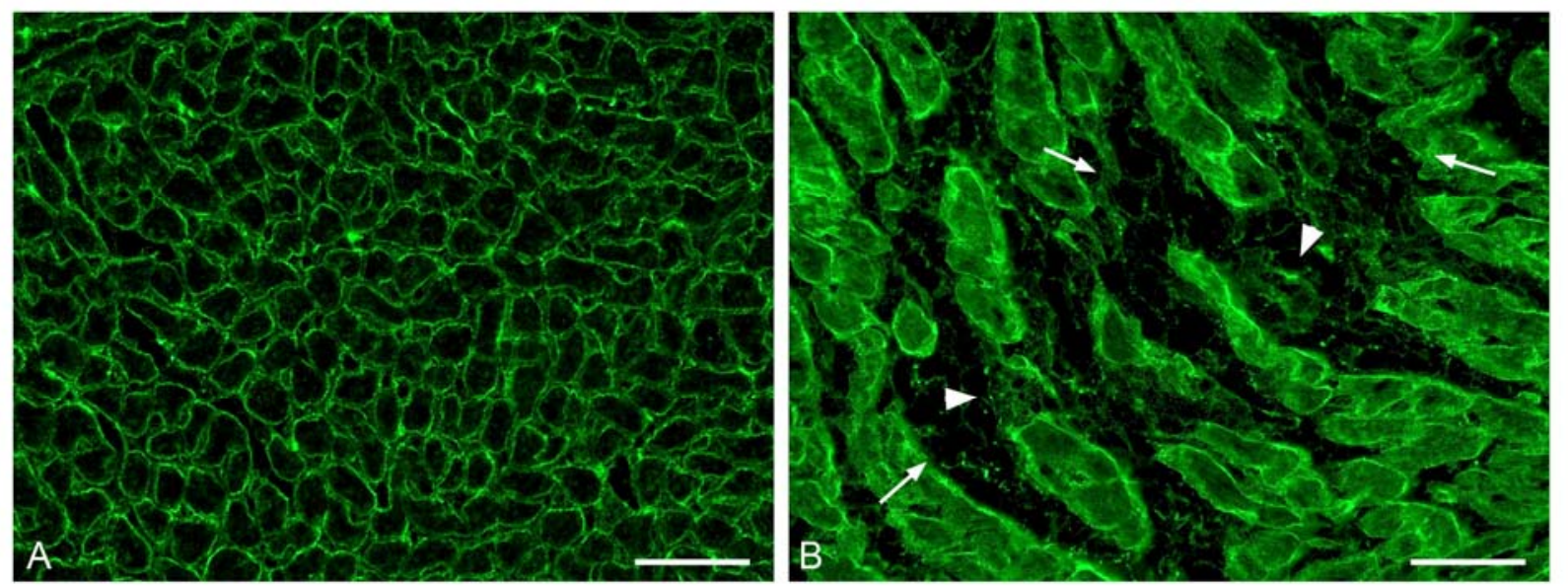

Figura 9: Imunofluorescência para $\beta-1$ integrina. A) Grupo controle: marcação uniforme da $\beta-1$ integrina delineando o perfil externo dos miócitos. B) Grupo tratado com isoproterenol: redução da marcação, mas persistência do perfil miocelular delineado pela $\beta-1$ integrina (flechas) e áreas de colapso (cabeças das flechas). Barra $=50 \mu \mathrm{m}$.
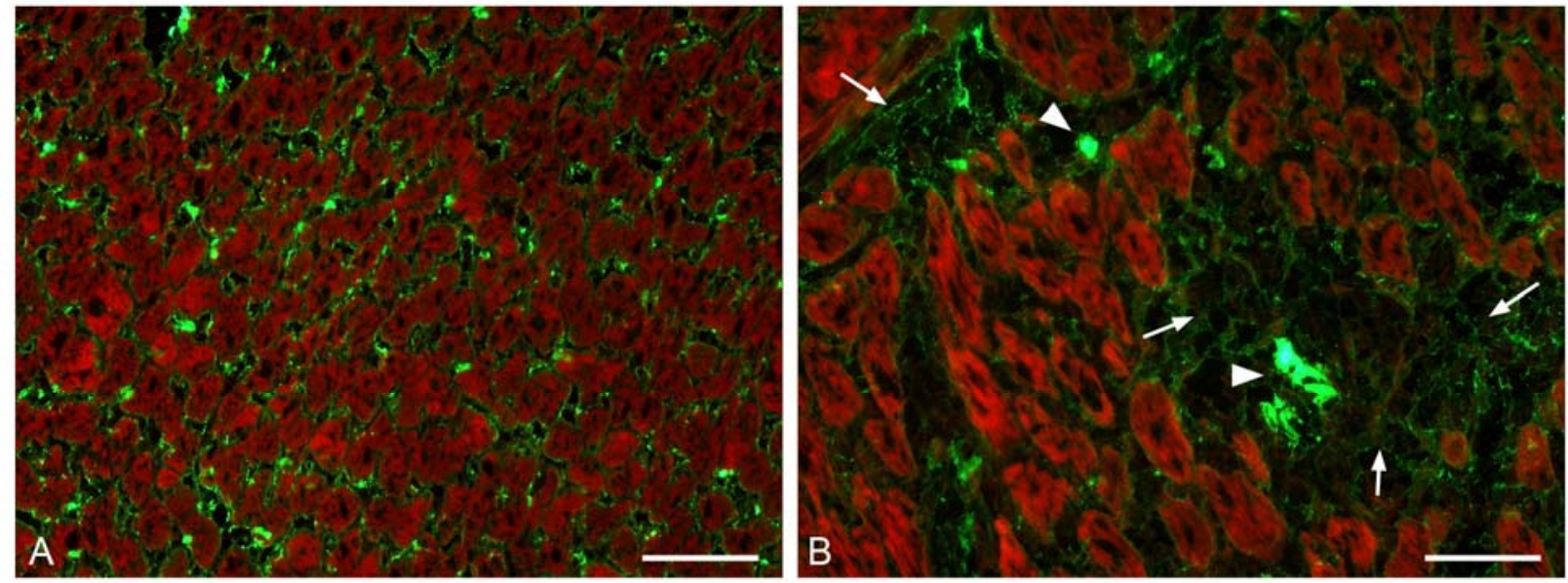

Figura 10: Imunofluorescência para merosina laminina $\alpha-2$ (fluorescência verde) e actina (faloidina, fluorescência vermelha). A) Grupo controle: marcação uniforme da merosina laminina $\alpha-2$ delineando o perfil externo dos miócitos; a actina marca todos os miócitos. B) Grupo tratado com isoproterenol: redução da marcação, mas persistência do perfil miocelular delineado pela merosina laminina $\alpha-2$ (flechas) e áreas de colapso (cabeças das flechas), com perda de actina. Barra $=50 \mu \mathrm{m}$. 


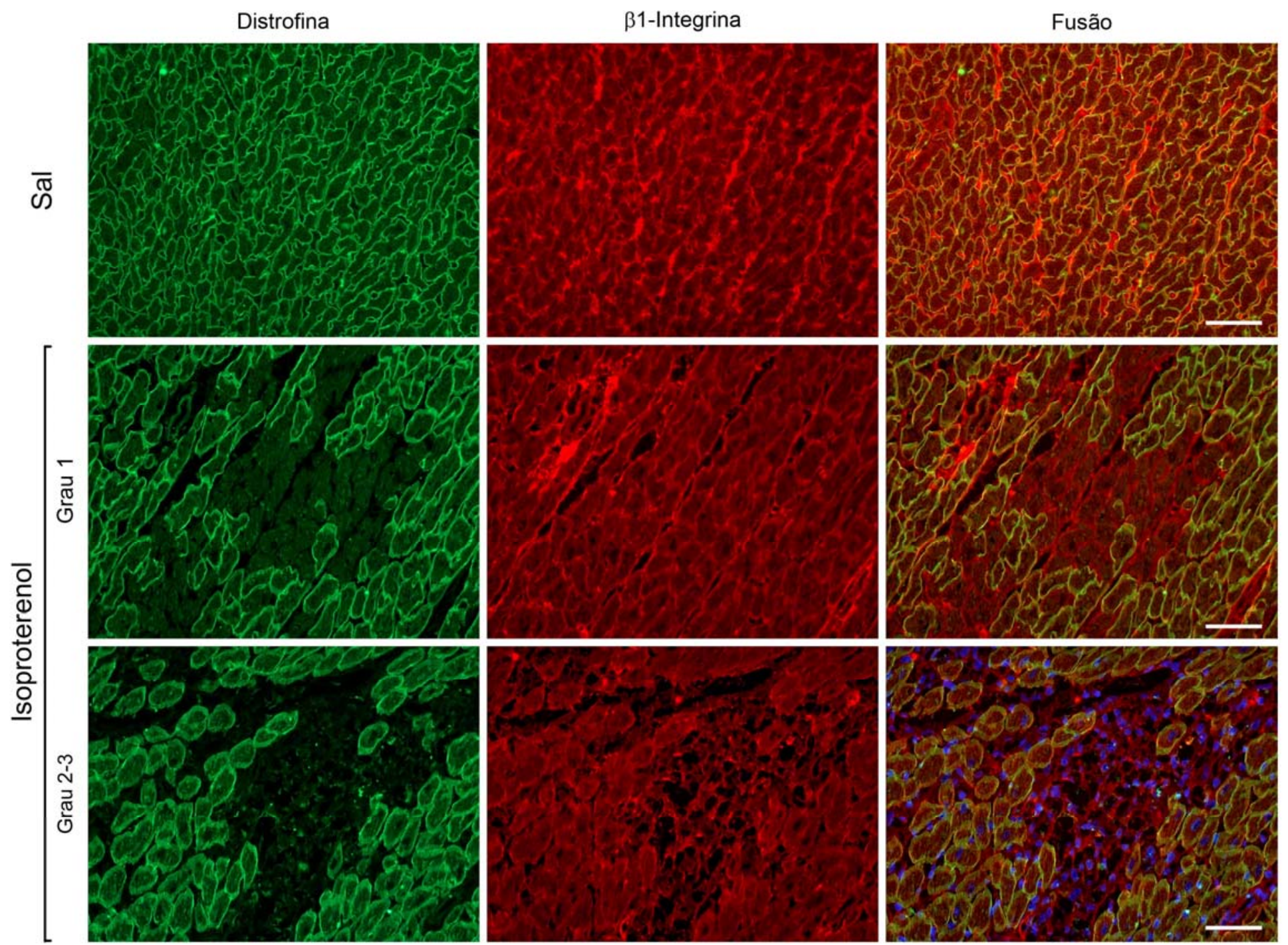

Figura 11: Imunofluorescência para distrofina (fluorescência verde) e $\beta 1$-integrina (fluorescência vermelha). Grupo controle (Sal): marcação uniforme da distrofina e da $\beta-1$ integrina, delineando o perfil dos miócitos. Grupo Isoproterenol: Lesão grau 1, perda da distrofina e expressão atenuada da $\beta-1$ integrina com persistência do perfil miocelular. Lesão graus 2-3, perda da distrofina e expressão atenuada ou o colapso da $\beta-1$ integrina. Na lesão graus $2-3$ a presença de infiltrado inflamatório mononuclear foi evidenciada através da marcação nuclear com DAPI (fluorescência azul). Barra = 50 $\mu \mathrm{m}$ 
Considerando que o dano ao sarcolema poderia levar ao aumento da permeabilidade da membrana, a integridade do sarcolema foi avaliada através da imunofluorescência com dupla marcação para distrofina e albumina. O miocárdio do grupo controle mostrou marcação uniforme para a distrofina e presença de albumina no interstício, apenas com marcação dos pequenos vasos. O miocárdio dos animais do grupo tratado com isoproterenol mostrou áreas focais de células com perda de distrofina e intenso acúmulo de albumina no espaço intracelular revelada pela fluorescência verde e vermelha para albumina e distrofina respectivamente, ou até mesmo áreas sem marcação para a distrofina, mas com albumina marcada irregularmente revelando as células, o que claramente demonstra alterações na permeabilidade da membrana dos miócitos tratados com isoproterenol (Figura 12). 

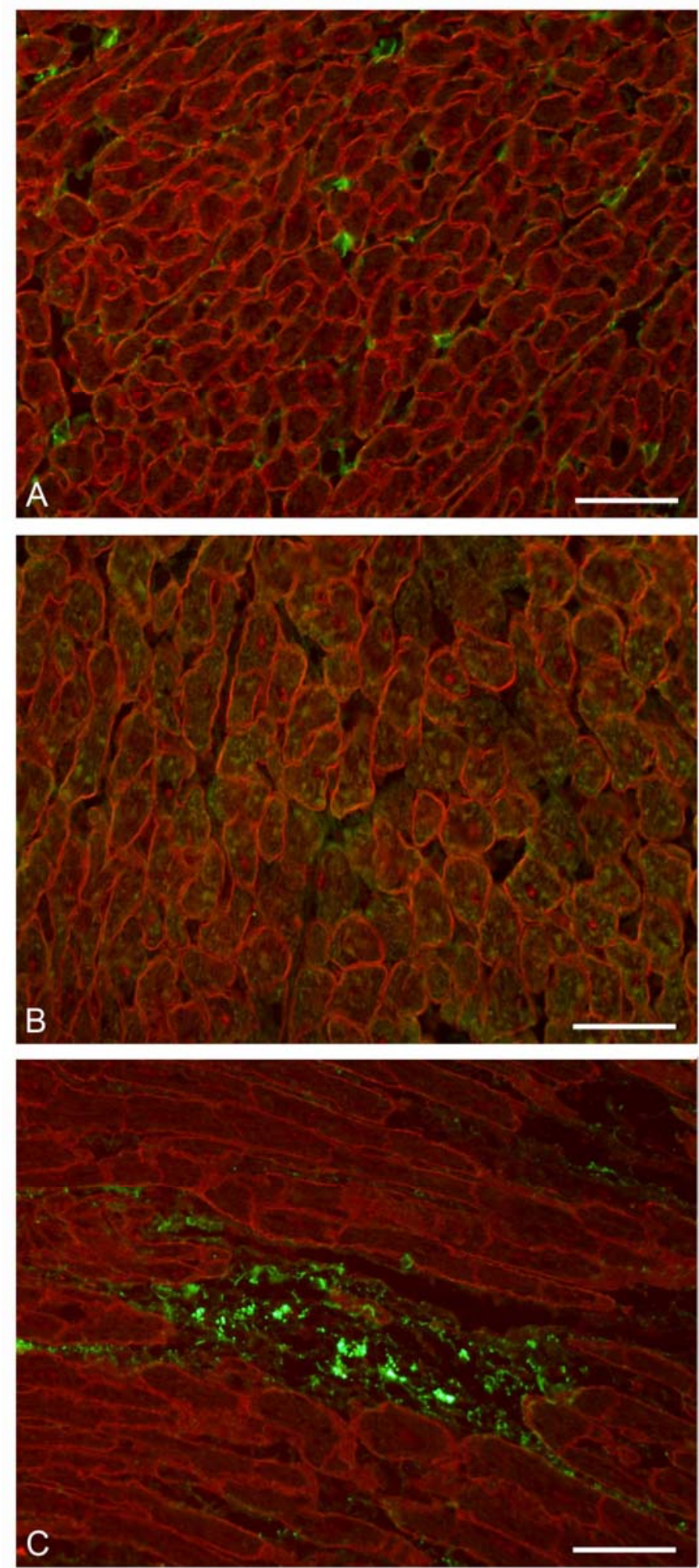

Figura 12: Imunofluorescência para albumina (fluorescência verde) e distrofina (fluorescência vermelha). A) Grupo controle: marcação uniforme da distrofina e presença de albumina no interstício apenas marcando os pequenos vasos. B e C) Grupo tratado com isoproterenol. B) Perda da distrofina e acúmulo de albumina no espaço intracelular do miócito cujo citoplasma fluoresce discretamente em verde. C) perda da distrofina e albumina marcada irregularmente revelando as células. Barra $=50 \mu \mathrm{m}$. 
Levando-se em consideração que mecanismos compensatórios desencadeados na isquemia induzida pelo isoproterenol estão ativados e é conhecido o efeito inotrópico negativo da enzima óxido nítrico sintase endotelial eNOS (Massion et al., 2005), a expressão da eNOS foi avaliada. Para este estudo, foi realizada imunofluorescência com dupla marcação para eNOS e faloidina. No miocárdio dos animais controle a marcação para eNOS foi positiva e marcou especificamente o endotélio dos pequenos vasos. No miocárdio dos animais tratados com isoproterenol, houve aumento na expressão de eNOS nos pequenos vasos, principalmente naqueles ao redor das áreas de miocitólise e, também no citoplasma dos miócitos adjacentes. A expressão de eNOS estava praticamente ausente nas áreas de miocitólise exceto nos pequenos vasos remanescentes do interstício (Figura 13). 

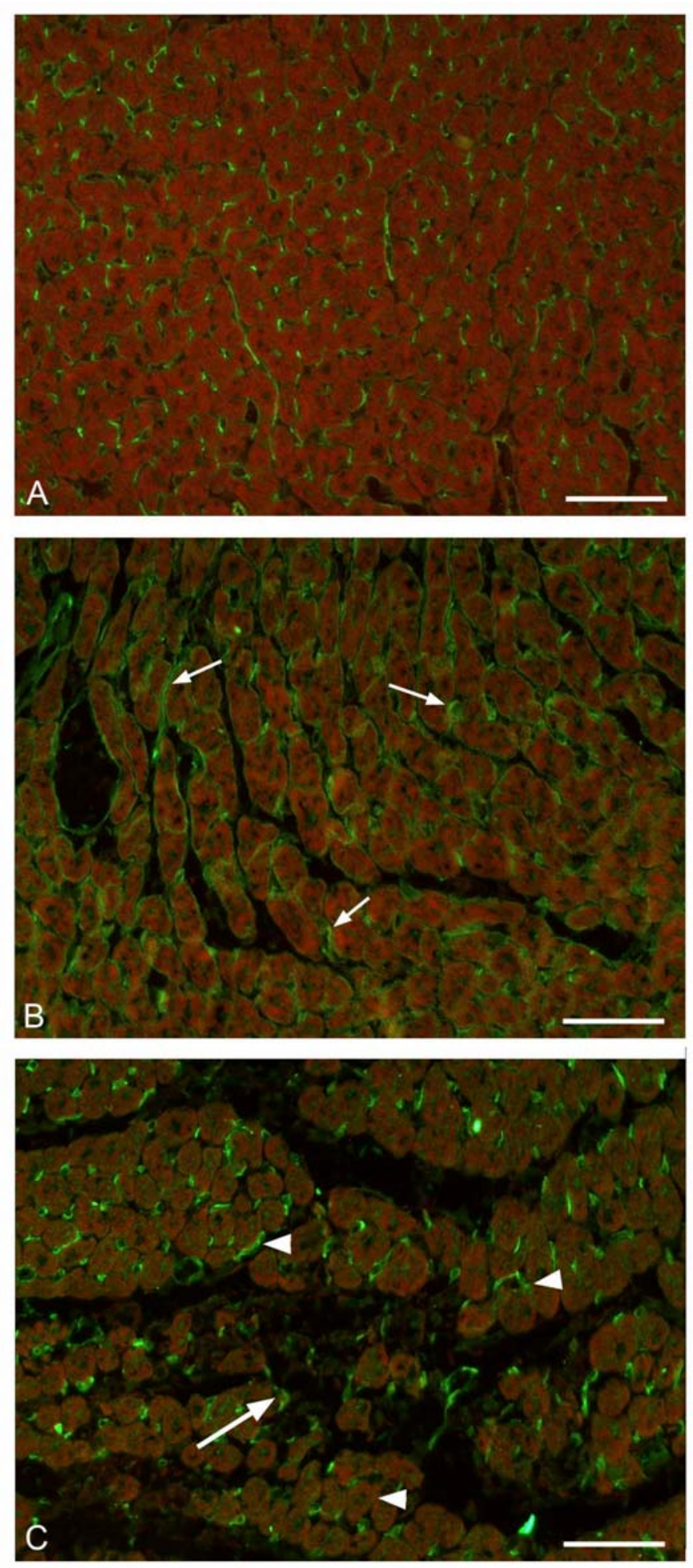

Figura 13: Imunofluorescência para eNOS (fluorescência verde) e actina (faloidina, fluorescência vermelha). A) Grupo controle: presença de actina e marcação positiva para eNOS no endotélio dos pequenos vasos. B e C) Grupo tratado com isoproterenol. B) Aumento da expressão de eNOS nos pequenos vasos perimiocitários (flechas) e no citoplasma das células, tornando menos distinta a fluorescência vermelha da actina (flechas). C) Área de miocitólise com perda de actina e ausência de marcação para eNOS (cabeças das flechas); fora da área de miocitólise nota-se, predominantemente em torno da área de miocitólise, a expressão de eNOS nos pequenos vasos perimiocitários. Barra $=50 \mu \mathrm{m}$. 
O infiltrado inflamatório observado na microscopia de luz foi caracterizado através da imunofluorescência utilizando-se anticorpos primários anti-macrófago (CD68), antilinfócitos (CD4) e anti-antígeno comum leucocitário (CD45). Não foram encontradas células inflamatórias no miocárdio dos animais controle. O miocárdio dos animais do grupo tratado com isoproterenol mostrou infiltrado inflamatório caracterizado principalmente por células com marcação positiva para CD68 nas áreas de miocitólise (Figura 14 A e B). A marcação para CD45 reproduziu a marcação observada na reação com anticorpo antiCD68. A marcação para CD4 foi negativa no miocárdio de ambos os grupos, controle e tratado com isoproterenol.

\subsection{AVALIAÇÃO DA APOPTOSE}

Considerando a predominância absoluta de macrófagos nas áreas de miocitólise, a presença de células apoptóticas foi avaliada utilizando-se o método do TUNEL. Nas áreas de miocitólise com grau 1 a marcação positiva para células apoptóticas foi constante e claramente notada nos cardiomiócitos. Nas áreas de miocitólise graus 2-3 tanto os cardiomiócitos quanto os macrófagos (infiltrado celular mononuclear) foram constante e claramente marcados (Figura $14 \mathrm{C}-\mathrm{E})$. 

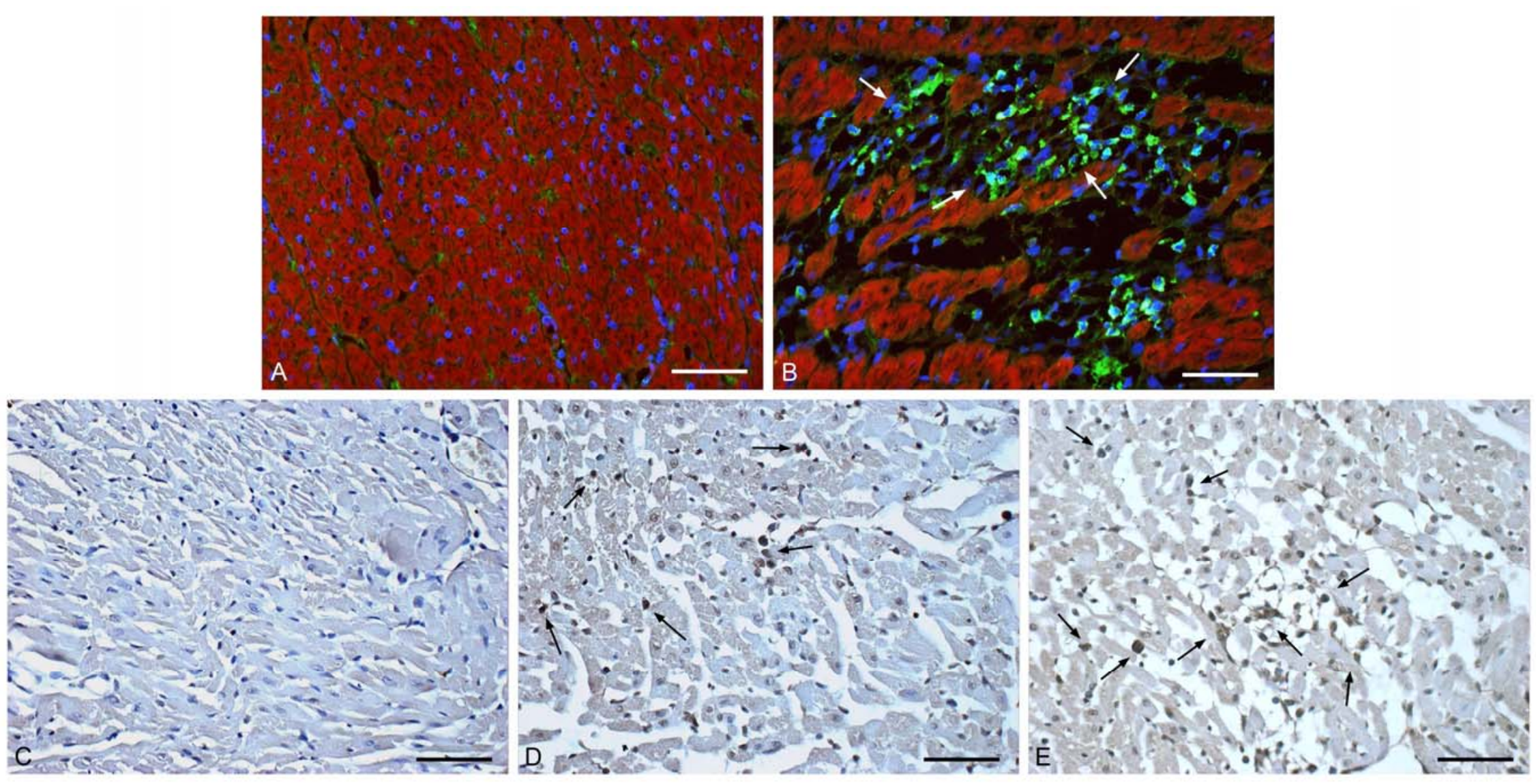

Figura 14: Imunofluorescência para CD68 (macrófagos, fluorescência verde), actina (faloidina, fluorescência vermelha) e marcação nuclear com fluorescência azul (DAPI). A) Grupo controle: presença de actina e ausência de macrófagos. B) Grupo tratado com isoproterenol: área de miocitólise com perda de actina e presença de infiltrado inflamatório predominantemente caracterizado por macrófagos (flechas). Método do TUNEL (C-E). C) Grupo controle: ausência de células apoptóticas. Grupo tratado com isoproterenol. B) Lesão grau 1 e C) Lesão graus 2-3. Em B e C observa-se marcação positiva para apoptose nos macrófagos

$\mathrm{e}$

nos

cardiomiócitos

(flechas).

Barra

$50 \mu \mathrm{m}$. 


\subsection{ECOCARDIOGRAFIA}

O peso corporal inicial dos animais do grupo controle variou de 292 a 348 g (média 326 g) e, dos animais dos grupos tratados com isoproterenol $85 \mathrm{mg} / \mathrm{kg}$, o peso corporal inicial variou de 277 a $340 \mathrm{~g}$ (média $303 \mathrm{~g}$ ), e $150 \mathrm{mg} / \mathrm{kg}$, variou de 289 a 328 g (média $315 \mathrm{~g}$ ). O peso corporal final dos animais do grupo controle variou de 317 a 374 g (média 350 g) e, dos animais dos grupos tratados com isoproterenol $85 \mathrm{mg} / \mathrm{kg}$, o peso corporal final variou de 266 a 363 g (média 296 g), e $150 \mathrm{mg} / \mathrm{kg}$, variou de 287 a 328 g (média 301 g). Houve um retardo no ganho de peso corporal dos animais tratados com isoproterenol 85 e 150 $\mathrm{mg} / \mathrm{kg}(296 \pm 8,33$ e $301 \pm 4,79 \mathrm{~g}$, respectivamente) em relação aos animais do grupo controle $(350 \pm 3,74 \mathrm{~g})$. A freqüência cardíaca durante o exame de ecocardiografia não foi significativamente diferente entre os grupos: os animais do grupo controle apresentaram freqüência cardíaca de $311 \pm 13,6$ bpm e os animais dos grupos tratados com 85 e $150 \mathrm{mg} / \mathrm{kg}$ de isoproterenol apresentaram $341 \pm 14,2$ e $343 \pm 12,9 \mathrm{bpm}$, respectivamente. As imagens bidimensionais e do modo-M obtidas ao nível dos músculos papilares mostraram diferenças significativas em relação ao DDVE e DSVE entre os animais dos grupos controle $(0,600 \pm 0,01$ e $0,271 \pm 0,02 \mathrm{~cm}$, respectivamente) e tratado com isoproterenol $85 \mathrm{mg} / \mathrm{kg}$ $(0,709 \pm 0,02$ e $0,368 \pm 0,02 \mathrm{~cm}$, respectivamente $)$ e $150 \mathrm{mg} / \mathrm{kg}(0,698 \pm 0,04$ e $0,380 \pm 0,04 \mathrm{~cm}$, respectivamente) (Figura 15). Não foi observada diferença nos valores da fração de encurtamento do ventrículo esquerdo e na fração de ejeção (FE) entre os grupos controle $(48,56 \pm 1,96$ e $85,57 \pm 1,30 \%$, respectivamente), e tratado com isoproterenol $85 \mathrm{mg} / \mathrm{kg}$ $(51,39 \pm 3,06$ e $85,68 \pm 1,70 \%$, respectivamente) e $150 \mathrm{mg} / \mathrm{kg}(47,95 \pm 2,74$ e $83,70 \pm 2,65 \%$,

respectivamente). Os valores estão resumidos na tabela 2. A figura 16 mostra a representação ecocardiográfica no modo-M de animais do grupo controle e tratado com isoproterenol. 
Tabela 2: Parâmetros ecocardiográficos dos grupos controle e tratado com isoproterenol.

\begin{tabular}{lccc}
\hline Parâmetros & Controle $(\boldsymbol{n}=\mathbf{9})$ & ISO 85 $\mathbf{~ m g} / \mathbf{k g}(\boldsymbol{n}=\mathbf{1 2})$ & ISO 150 mg/kg (n=8) \\
\hline Peso final (g) & $350 \pm 3,74$ & $296 \pm 8.33^{* * *}$ & $301 \pm 4.79^{* * *}$ \\
Freqüência cardíaca (bpm) & $311 \pm 13.6$ & $341 \pm 14.2(\mathrm{NS})$ & $343 \pm 12.9(\mathrm{NS})$ \\
DDVE (cm) & $0,600 \pm 0,01$ & $0,709 \pm 0,02^{*}$ & $0,698 \pm 0,04^{*}$ \\
DSVE (cm) & $0,271 \pm 0,02$ & $0,368 \pm 0,030^{* *}$ & $0,380 \pm 0,04^{*}$ \\
Fração Encurtamento VE (\%) & $48,56 \pm 1,96$ & $51,39 \pm 3,06(\mathrm{NS})$ & $47,95 \pm 2,74$ (NS) \\
Fração de ejeção (\%) & $85,57 \pm 1,30$ & $85,68 \pm 1,70(\mathrm{NS})$ & $83,70 \pm 2,65$ (NS) \\
\hline
\end{tabular}

Os dados são a média \pm erro padrão da média. ${ }^{*} \mathrm{p}<0,05 ;{ }^{* *} \mathrm{p}<0,0001$; NS, não significante. VE, ventrículo esquerdo; VD, ventrículo direito; bpm, batimentos/min; ISO, isoproterenol; Diâmetro diastólico final VE (DDVE); Diâmetro sistólico final VE (DSVE). 
A
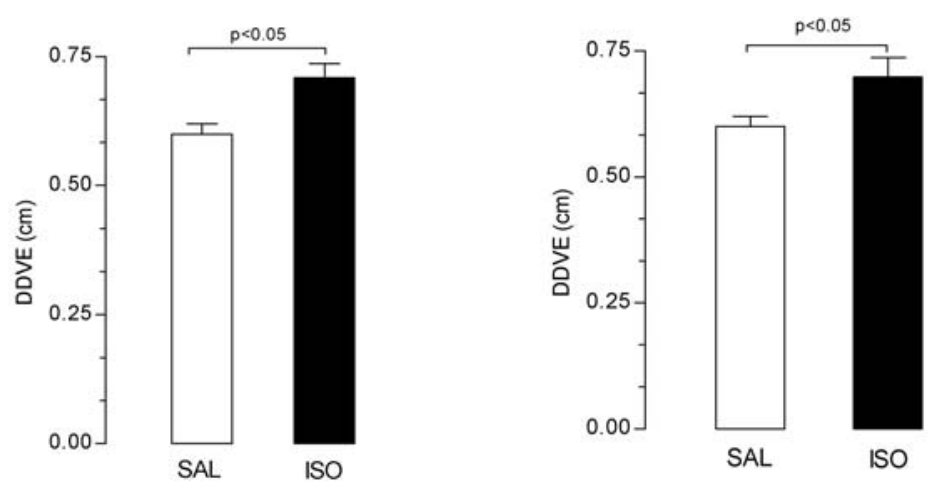

B
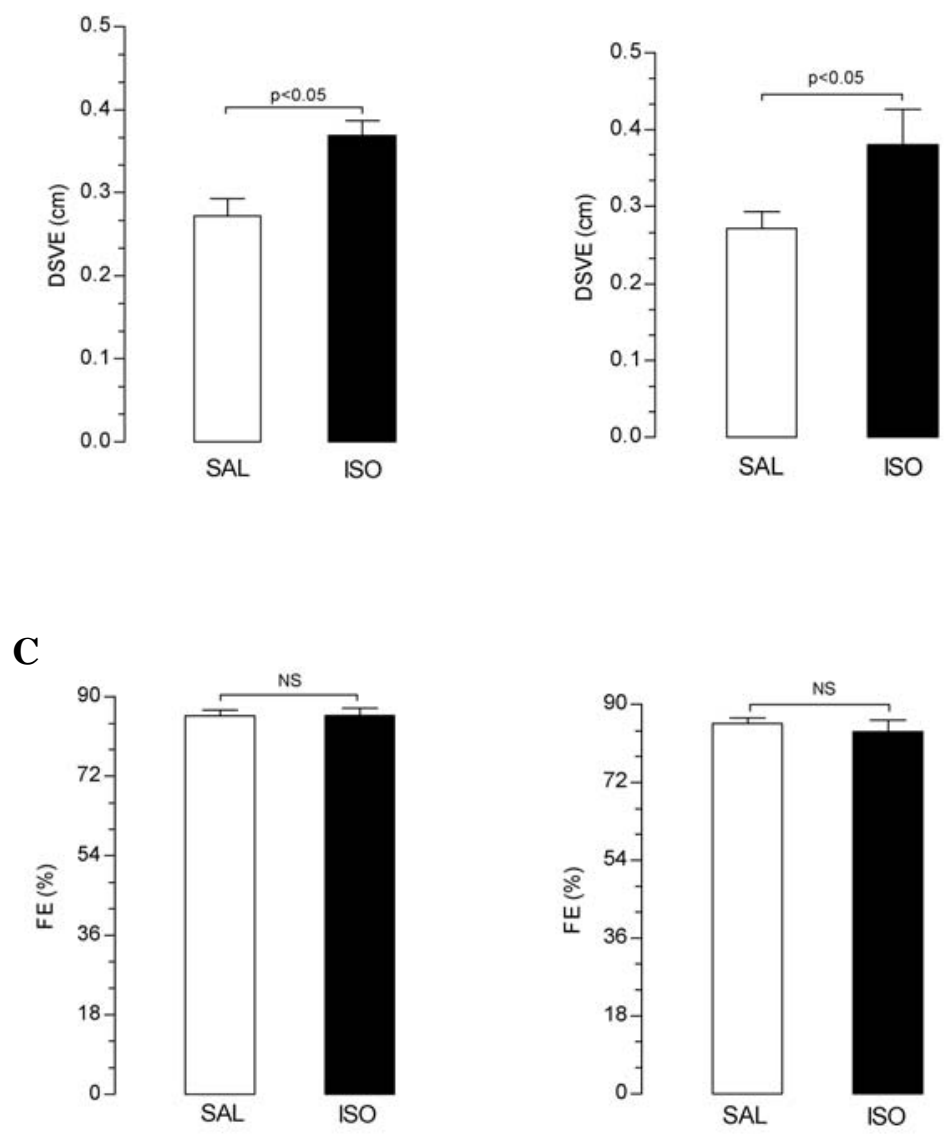

Figura 15: Diâmetros diastólico (A) e sistólico (B) do ventrículo esquerdo e fração de ejeção (C). Os dados são a média + erro padrão da média, ${ }^{*} \mathrm{p}<0,05$; NS, não significante. DDVE, diâmetro diastólico do ventrículo esquerdo; DSVE, diâmetro sistólico do ventrículo esquerdo; FE, fração de ejeção. 

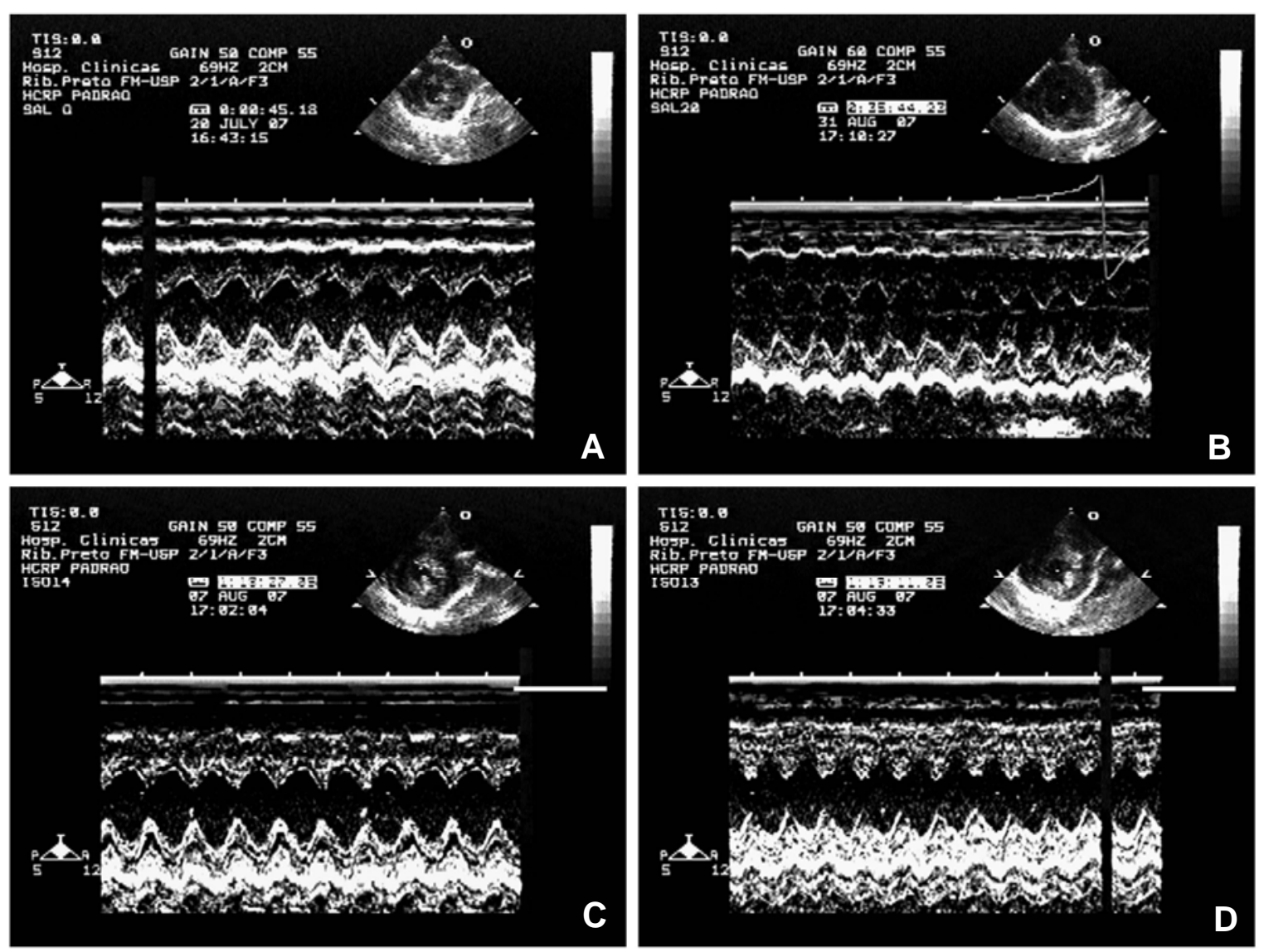

Figura 16: Representação ecocardiográfica do modo-M, visão paraesternal do eixo curto ao nível dos músculos papilares. A e C) Animais do grupo controle. B) Animal do grupo tratado com isoproterenol 85 $\mathrm{mg} / \mathrm{kg}$. D) Animal do grupo tratado com isoproterenol $150 \mathrm{mg} / \mathrm{kg}$. 
O escore de mobilidade de parede foi utilizado no presente estudo levando em conta que o mesmo provê um acurado índice semiquantitativo da função ventricular em humanos e em pequenos animais (Morgan et al., 2004; Zhang et al., 2007). A média dos escores de mobilidade nas regiões basal e média nos animais tratados com isoproterenol $85 \mathrm{mg} / \mathrm{kg}(1 \mathrm{e}$ $1,04+0,04$, respectivamente) ou $150 \mathrm{mg} / \mathrm{kg}$ (1 e 1,12+0,09, respectivamente) foram similares aos valores correspondentes nos animais do grupo controle (1 para ambos os segmentos). Em relação ao escore de mobilidade de parede da região apical encontramos uma importante diferença entre os animais dos grupos tratados com isoproterenol $85 \mathrm{mg} / \mathrm{kg}$ $(2,21 \pm 0,34)$ e $150 \mathrm{mg} / \mathrm{kg}(2,70 \pm 0,20)$ quando comparados aos animais do grupo controle (1). (Figura 17).

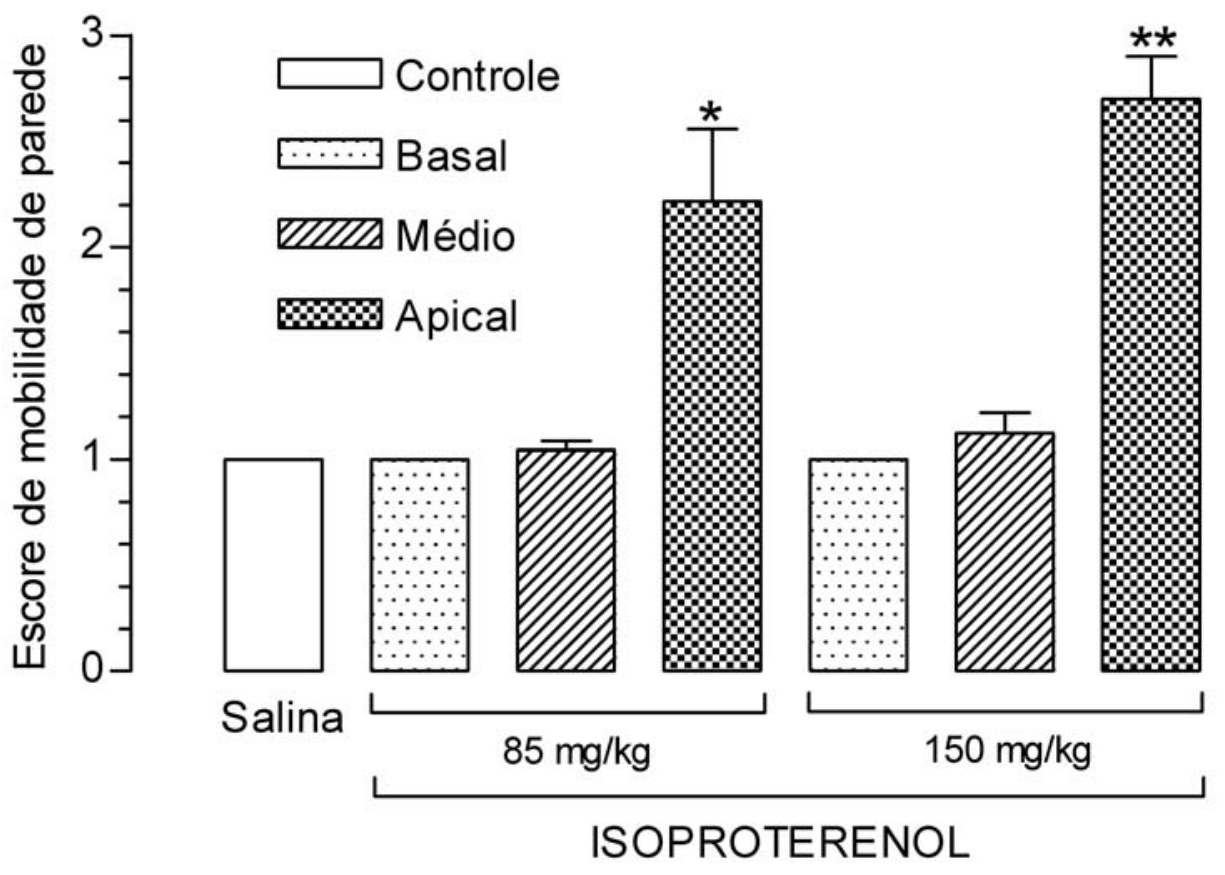

Figura 17: Escore de mobilidade de parede dos animais do grupo controle e tratados com isoproterenol 85 $\mathrm{mg} / \mathrm{kg}$ ou $150 \mathrm{mg} / \mathrm{kg}$. Os dados são a média \pm erro padrão da média, ${ }^{*} \mathrm{p}<0,05 \mathrm{e} * * \mathrm{p}<0,01$. 


\section{DISCUSSÃO}

A administração de isoproterenol foi eficiente na indução da lesão semelhante ao infarto em animais, como descrito previamente (Rona et al., 1959; Ferrans et al., 1964). A microscopia óptica comum e de alta resolução revelou que o miocárdio dos animais tratados com isoproterenol apresentou áreas de miocitólise classificáveis em três graus distintos e diferentes de gravidade que podem ser descritos numa aparente seqüência de eventos: primeiro, observamos focos de células miocárdicas tumefeitas e degeneração vacuolar, segundo, focos de miocitólise associados a infiltrado inflamatório composto predominantemente por macrófagos, e terceiro, áreas focais com ausência de miofibras e escassa presença de macrófagos. Nessa fase aguda, após administração de isoproterenol, o papel principal desempenhado pelos macrófagos é o de fagocitar os debris celulares. Sua

presença torna-se menos comum após a remoção do material fagocitado, seguido pela chegada de fibroblastos ao foco de lesão (van Amerongen et al., 2007). Muitos macrófagos e cardiomiócitos apoptóticos foram encontrados nos corações dos animais tratados com isoproterenol. Portanto, a apoptose desempenha papel importante no desaparecimento das células miocárdicas e do infiltrado celular mononuclear após a administração de isoproterenol. Essa observação corrobora com achados anteriores de que a ativação $\beta$ adrenérgica causa morte dos cardiomiócitos tanto por necrose quanto por apoptose (Remondino et al., 2003). As lesões miocitolíticas estão predominantemente localizadas no ápice cardíaco, regiões subendocárdicas e subepicárdicas dos ventrículos esquerdo e direito e região subendocárdica do septo interventricular. As áreas de miocitólise representaram $26,89 \%, 36,12 \%$ e $28,15 \%$ da área total do ventrículo esquerdo, septo e ventrículo direito, respectivamente.

$\mathrm{Na}$ lesão induzida pelo uso de isoproterenol, os cardiomiócitos podem ser afetados em sua estrutura e função. Os cardiomiócitos são células especializadas em converter energia química em trabalho mecânico, que resulta em deformação das miofibrilas. O sistema contrátil de dentro das miofibrilas está intimamente conectado à membrana e à matriz 
extracelular através das proteínas que compõem o complexo de glicoproteínas associadas à distrofina, a integrina e a laminina, sendo que qualquer interferência na estrutura e nas funções das mesmas pode acarretar a perda de função e a morte celular (Lapidos et al., 2004).

O presente estudo demonstrou sensibilidade diferente dos componentes do complexo de glicoproteínas asssociadas à distrofina após administração de isoproterenol. Particularmente, a imunofluorescência revelou que a distrofina, um componente do citoesqueleto submembrana, é a mais sensível entre as estruturas que conectam a actina do citoesqueleto dos cardiomiócitos e a matriz extracelular representada pela laminina no presente estudo. Além disso, os dados mostraram que a dissolução da actina sarcomérica como parte do processo de miocitólise ou degeração miofibrilar, ocorreu após a redução ou a perda da distrofina. Subsenqüentemente à lise dos miofilamentos, a expressão da $\gamma$ sarcoglicana, $\beta$-distroglicana, $\beta 1$-integrina e laminina está reduzida, seguido pelo seu colapso. A dupla marcação confirmou claramente que a perda da distrofina ocorreu anterior à redução da expressão dos elementos remanescentes do complexo de glicoproteínas associadas à distrofina. É conhecido que a perda da distrofina leva à instabilidade secundária dos demais componentes do complexo de glicoproteínas (Ervasti et al. 1990). A distrofina se localiza logo abaixo do sarcolema e liga a actina através do complexo de glicoproteínas à matriz extracelular. Tem como função principal estabelecer uma ponte de ligação para a transferência da força mecânica gerada no sistema contrátil à matriz extracelular ou transmitir estímulo mecânico para o meio intracelular. Outra função fisiológica da distrofina é a de prevenir a expansão excessiva do sarcolema durante a contração muscular (Xi et al., 2000). A interação entre a distrofina e as distroglicanas e sarcoglicanas é importante para manter a relação espacial entre os componentes do citoesqueleto e a matriz extracelular nas células musculares. O complexo de distroglicana é importante na organização da matriz extracelular, especialmente através da interação com a laminina (Mcnally et al., 2003), mantendo a contínua ligação entre o citoesqueleto e a matriz extracelular (Winder, 2001). O complexo das sarcoglicanas compõe-se das subunidades $\alpha, \beta, \gamma, \varepsilon, \zeta$ e $\delta$-sarcoglicanas e, assim como a distrofina e as distroglicanas, 
estão envolvidas nas distrofias musculares (Kaprielian \& Severs, 2000; Winder, 2001; Ganote \& Armstrong, 2002; Kawada et al., 2005). Além do papel desempenhado pela distrofina, as distroglicanas e sarcoglicanas também são importantes para a manutenção da integridade do sarcolema (Lapidos et al., 2004). A perda de $\delta$-sarcoglicana resulta na dissociação do complexo de distroglicanas do complexo das sarcoglicanas, causando dano à integridade do sarcolema e à matriz extracelular com conseqüente distrofia muscular e cardiomiopatia (Straub et al., 1998). Recentemente, demonstrou-se que a proteólise da distroglicana rompe a ligação entre o sarcolema e a matriz extracelular, que leva a degeneração muscular esquelética e a cardiomiopatia (Matsumura et al., 2003). A perda primária ou secundária de sarcoglicanas do sarcolema leva à degeneração celular focal. $\mathrm{O}$ processo degenerativo associado com a perda da distrofina é caracterizado como necrose, embora haja pequeno, mas significante aumento nos núcleos apoptóticos evidenciados pelo método do TUNEL (Tidball et al., 1995; Mcnally et al., 2003). As integrinas ( $\alpha$ e $\beta$ ), consideradas proteínas transmembrana, são os principais receptores de adesão intercelular e estão envolvidas na manutenção da integridade celular e extracelular. Têm como funções principais, a ligação entre a matriz extracelular e o citoesqueleto e a transmissão de sinais bioquímicos e da força mecânica ao longo do sarcolema (Calderwood et al., 2000; van Der Flier \& Sonnenberg 2001; Delon \& Brown, 2007). A expressão da integrina parece estar intimamente relacionada e coordenada com a formação da matriz extracelular no coração adulto, e sua adequada expressão é necessária para uma função cardiovascular normal (Ross, 2002). A perda da associação entre as estruturas do complexo de glicoproteínas associadas à distrofina pode causar perda da integridade sarcolemal e degeneração miofibrilar, com conseqüente prejuízo da função contrátil (Rybakova et al., 2000; Lapidos et al., 2004; Heydemann \& Mcnally, 2007). A expressão da laminina ainda estava presente, mas atenuada, nas áreas de miocitólise. Destacamos ainda, que nessas mesmas áreas, a laminina apresentava-se colapsada. A laminina (merosina) é o maior componente da membrana basal e conecta a actina à matriz extracelular (Mcnally et al., 2003). A perda da ligação entre a matriz extracelular e a actina é um fator determinante para necrose das miofibras (Kido et al., 2004; Allikian \& Mcnally, 2007). A diminuição da expressão da 
laminina ocorre durante a transição para insuficiência cardíaca e predispõe os cardiomiócitos a apoptose, similar ao que ocorre nas distrofias musculares (Berk et al., 2007).

Tanto quanto saibamos, este é o primeiro relato que demonstra um padrão de sensibilidade das proteínas de ligação que compõem o citoesqueleto ao isoproterenol em um experimento. Estudo recente demonstrou sensibilidades diferentes das proteínas relacionadas à membrana na isquemia miocárdica experimental através da ligadura da artéria coronária esquerda em cachorros, onde, similarmente, a distrofina foi mais acometida do que as demais proteínas transmembrana distroglicanas, sarcoglicanas, sarcospana, distrobrevina e sintrofina, e que esta perda de ligação com o restante do citosesqueleto desestabiliza e deixa os miócitos mais vulneráveis ao dano isquêmico (Rodríguez et al., 2005).

Marcação imunoistoquímica anormal para distrofina na lesão miocárdica induzida pelo isoproterenol (administração subcutânea de $100 \mathrm{mg} / \mathrm{kg}$ ) em ratos foi descrita anteriormente por Miyazato et al. (1997). Em contraste com nossos achados, os autores relataram que os cardiomiócitos apresentaram três padrões diferentes de marcação: normal para actina, mas anormal para distrofina, anormal para actina, mas normal para distrofina e anormal para ambos, actina e distrofina. Os autores ressaltaram que os dois últimos padrões podem ter sido desviados devido à baixa sensibilidade ao método de imunoistoquímica, caso contrário haveria mais de um mecanismo responsável pela lesão miocárdica induzida pelo isoproterenol. Em outro estudo, a proposta foi correlacionar a perda da distrofina com a ocorrência de apoptose no período compreendido entre 4 a 18 horas após a administração intraperitoneal de isoproterenol $(10 \mathrm{mg} / \mathrm{kg})$. A degradação da distrofina seguida por apoptose dos cardiomiócitos progrediu em função da variação da duração do experimento. Nesse mesmo estudo os autores comentam ainda que a integridade do complexo de glicoproteínas associadas à distrofina pode prevenir a apoptose dos cardiomiócitos na lesão aguda induzida pelo isoproterenol (Xi et al., 2000). Recentemente, a insuficiência cardíaca após administração intraperitoneal aguda de isoproterenol $(10 \mathrm{mg} / \mathrm{kg})$ demonstrou estar associada ao rompimento da distrofina no miocárdio em falência (Toyo-Oka et al., 2004; 
Kawada et al., 2005). Estudo mais recente mostrou que a inibição da via de sinalização da apoptose regulada pela quinase-1 (ASK1) pode evitar a progressão para insuficiência cardíaca pela prevenção da apoptose do cardiomiócito e pela inibição da clivagem da distrofina mediada pela calpaína em hamsters com cardiomiopatia (Hikoso et al., 2007).

Considerando nossos achados, tenta-se especular a hipótese de um mecanismo molecular da lesão miocárdica induzida pelo isoproterenol: a redução ou a perda da distrofina pode ser o evento primário que ocorre seguido pela degeneração miofilamentar e lise dos cardiomiócitos. Essa hipótese é sustentada por observações feitas na distrofia muscular de Duchenne produzida pela mutação do gene da distrofina no cromossomo X e em modelos murinos de mutação do gene da distrofina. Em cada uma das situações, a perda da distrofina desestabiliza o complexo de proteínas associadas a ela no sarcolema causando a destruição do miócito. Essa desestabilização do sarcolema também altera a permeabilidade da membrana levando ao aumento do conteúdo de cálcio intracelular (Straub et al., 1997), que por sua vez, estimula as proteases cálcio-ativadoras (calpaínas) que são capazes de fazer a proteólise das proteínas intracelulares, contribuindo para a destruição da célula muscular (Turner et al., 1991). A estimulação inotrópica excessiva e a ativação de cálcio dependente da adenosina trifosfatase são fatores principais que causam alterações nos miofilamentos (Rona et al., 1973). Tem sido demonstrado que a administração subcutânea de isoproterenol causa aumento da permeabilidade de membrana (Yunge et al., 1989) com aumento da concentração de cálcio intracelular, severo dano à fibra miocárdica, morte celular (Milei et al., 1978; Fleckenstein et al., 1983), e conseqüentemente, depressão da função contrátil (Tappia et al., 2001). A alta dose de isoproterenol altera a manutenção da homeostase do cálcio intracelular primariamente através de reações de oxidação com envolvimento de radicais livres, os quais promovem peroxidação lipídica com conseqüente dano ao sarcolema e aumento de permeabilidade (Singal et al., 1982; Dhalla et al., 1996; Tappia et al., 2001). Neste trabalho, a correlação entre a perda de distrofina e dano ao sarcolema com aumento de permeabilidade da membrana foi avaliado através da imunofluorescência para distrofina e albumina. No miocárdio dos animais do grupo controle, houve distribuição uniforme da distrofina, que delimitou bem a membrana e, a 
albumina, que marcou apenas os pequenos vasos. O miocárdio dos animais tratados com isoproterenol mostrou áreas focais de células com perda de distrofina e acúmulo de albumina no espaço intracelular ou áreas com perda de actina e acúmulo de albumina ocupando o lugar das células. Isto indica lesão grave ou irreversível dos cardiomiócitos. Em estudo feito em animais com deficiência de distrofina, os autores relataram que as fibras musculares marcadas com azul de Evans estavam transitória ou permanentemente permeáveis à albumina extracelular e outras proteínas séricas. Os pesos moleculares e os tamanhos desses marcadores séricos permitiram aos autores concluírem sobre a extensão do dano sarcolemal nas fibras afetadas (Straub et al., 1997). A correlação positiva entre a perda de distrofina e aumento da permeabilidade celular foi primeiramente descrita em estudo prévio com células isoladas (Armstrong et al., 2001). A perda primária e específica da distrofina pode explicar a base molecular fundamental da lesão miocárdica isquêmica irreversível (Fishbein et al., 1986; Armstrong et al., 2001; Rodríguez et al., 2005).

Uma questão importante é "qual o mecanismo de redução da expressão da distrofina nos corações dos animais tratados com isoproterenol?" Primeiro, o estresse induzido pela isquemia poderia levar a perda da distrofina sarcolemal. A isquemia aguda pode causar perda da imunomarcação para distrofina e corresponde à depleção de distrofina nos cardiomiócitos in vitro (Armstrong et al., 2001). Segundo, o estresse mecânico poderia causar um estado de fragilidade da ligação distrofina-actina pela indução de alterações estruturais da distrofina. Alterações na expressão genética levam à mudança na expressão da distrofina in vivo (Sadoshima \& Izumo, 1997). Terceiro, as proteases endógenas e exógenas poderiam causar perda da expressão de distrofina. Tem sido demonstrado que a protease 2A cliva diretamente a distrofina durante a infecção por vírus Coksackie em cultura de miócitos cardíacos e em corações de camundongos prejudicando a função da distrofina (Xiong et al., 2007).

O complexo de glicoproteínas associadas à distrofina também desempenha papel na sinalização celular através das enzimas óxido nítrico sintases (Heydemann et al., 2004). A enzima óxido nítrico sintase endotelial (eNOS) está expressa no sarcolema e cavéolas dos túbulos T, que ocupam o mesmo lugar dos receptores beta 3-adrenérgicos no coração e nas 
células endoteliais (Massion et al., 2005). As enzimas óxido nítrico sintases são responsáveis pelo efeito inotrópico negativo através da sinalização celular pela liberação de óxido nítrico (Rozec et al., 2003). É sabido que a atenuação dos receptores $\beta 1 / \beta 2$ adrenérgicos aumenta o intropismo e o cronotropismo e reforça o controle vagal da contração cardíaca, e por meio disso previne a excessiva estimulação pelas catecolaminas através do efeito vasodilatador do NO. Em nossos achados, a expressão de eNOS estava praticamente ausente nas áreas de miocitólise, exceto nos pequenos vasos intersticiais remanescentes ao redor da área de lesão que apresentaram marcação mais proeminente em comparação com o miocárdio dos animais controles. Esses achados diferem dos resultados de estudo anterior realizado com camundongos deficientes de sarcoglicana, onde os autores relatam que a expressão de eNOS está aumentada especificamente nos cardiomiócitos lesados (Heydemann et al., 2004). Estudo recente demonstrou uma menor expressão de eNOS nos vasos sangüíneos e nos cardiomiócitos após infarto do miocárdio experimental em ratos (Berges et al., 2007). Especulamos que a maior expressão de eNOS, observada no citoplasma dos cardiomiócitos e nos pequenos vasos ao redor da área de miocitólise, sugere uma resposta compensatória à isquemia provocada pelo isoproterenol na tentativa de melhora do fluxo sangüíneo para as áreas de lesão.

A análise morfométrica mostrou um aumento de $20 \%$ na área da câmara ventricular esquerda e um decréscimo de $26 \%$ na espessura da parede ventricular direita no miocárdio dos animais tratados com isoproterenol. A média da espessura das paredes ventricular esquerda e do septo interventricular não foram significativamente diferentes entre os grupos, embora esses valores apresentem tendência a diminuir nos corações dos animais tratados com isoproterenol. A ocorrência de aumento na câmara ventricular esquerda e redução na espessura da parede dos ventrículos direito e esquerdo e do septo nos animais tratados com isoproterenol avaliadas por morfometria são sugestivas de depressão da função miocárdica. Para confirmação desses dados foi proposta a análise da anatomia e função ventricular in vivo através da ecocardiografia. Os equipamentos ecocardiográficos de uso clínico são bastante utilizados em modelos experimentais com animais pequenos, mesmo possuindo limitações em relação à obtenção de imagens em alguns planos (Watson 
et al., 2004; Weytjens et al., 2006; Wasmeier et al., 2007). Os parâmetros avaliados pela ecocardiografia mostraram que os diâmetros sistólico e diastólico do ventrículo esquerdo estavam aumentados nos animais tratados com isoproterenol quando comparados aos animais controle, corroborando com os achados da morfometria. Em relação à fração de ejeção e função sistólica ventricular esquerda, os valores não indicaram alteração da função nos animais tratados com isoproterenol quando comparados com os do grupo controle. O curto período de duração do experimento, onde, provavelmente, os mecanismos compensatórios manteriam a função ventricular normal apesar de apresentarem severas alterações estruturais, poderiam explicar nossas observações. Estudo recente demonstrou que a administração crônica de isoproterenol a ratos promove dilatação e disfunção cardíacas sem insuficiência sistólica miocárdica intrínseca devido a um aumento da liberação de norepinefrina (Osadchii et al., 2007). Ademais, a localização predominante das lesões nos ápices dos corações, poderia, na fase precoce de análise, não refletir transtornos da ejeção e função sistólica ventricular esquerda. Devido a essas peculiaridades, o escore de mobilidade de parede foi usado como um índice adicional semiquantitativo da função miocárdica regional (Morgan et al., 2004). Hipocinesia ou acinesia nos segmentos apicais pôde ser observado nos corações dos animais tratados com isoproterenol em comparação com os controles. Essa observação confirma resultados anteriores de que o ápice cardíaco é a região mais acometida do coração onde predominam as lesões induzidas pelo isoproterenol (Rona et al., 1959).

Além disso, corroboram com a ocorrência de disfunção cardíaca, as alterações individuais em cada componente do complexo de glicoproteínas associadas à distrofina, na integrina e na laminina. A distrofina é o componente do complexo de glicoproteínas mais sensível à lesão miocárdica provocada pelo isoproterenol. A reduzida expressão ou colapso de $\gamma$ sarcoglicana, $\beta$-dystroglicana, $\beta 1$-integrina e laminina são considerados epifenômenos, ou seja, essas estruturas desempenharam um papel secundário no processo de miocitólise. Estudo recente utilizando amostras de biópsias miocárdicas de pacientes com insuficiência cardíaca mostrou alterações nas proteínas do citoesqueleto, e em particular que a falta da distrofina pode ser a via final para a disfunção contrátil na insuficiência cardíaca (Vatta et 
al., 2002). Estudo realizado em ratos demonstrou que a redução na expressão da distrofina e das sarcoglicanas desempenha um papel importante na patofisiologia da insuficiência cardíaca após infarto do miocárdio (Yoshida et al., 2003). Mais recentemente, um estudo usando hamsters com cardiomiopatia dilatada hereditária e corações humanos com cardiomiopatia dilatada mostraram que há uma estreita correlação entre a perda da distrofina e insuficiência cardíaca e que a perda da distrofina claramente precedeu a progressão da insuficiência cardíaca causada pela degradação dos cardiomiócitos (ToyoOka et al., 2004). 


\section{CONCLUSÃO}

Em sumário, a administração subcutânea de isoproterenol à ratos resulta na perda primária de distrofina, a estrutura mais sensível entre as proteínas do complexo de glicoproteínas associadas à distrofina que conecta a matriz extracelular ao citoesqueleto dos cardiomiócitos. A figura 18 mostra um diagrama esquemático representando a seqüencia de eventos observada: primeiro, a perda da distrofina e presença da actina sarcomérica, segundo, a perda da distrofina e graus variados de dissolução da actina sarcomérica e, terceiro, a perda da distrofina, da actina sarcomérica, e a redução da expressão da $\beta$ distroglicana, da $\gamma$-sarcoglicana, da $\beta 1$-integrina e da laminina $\alpha$-2. Essas mudanças, relacionadas à injúria isquêmica, podem explicar as graves alterações na integridade estrutural do sarcolema dos cardiomiócitos e a lesão provocada pelo isoproterenol. Mecanismos compensatórios no curto período de nosso experimento poderiam manter a função cardíaca normal apesar das graves alterações morfológicas encontradas. 
A

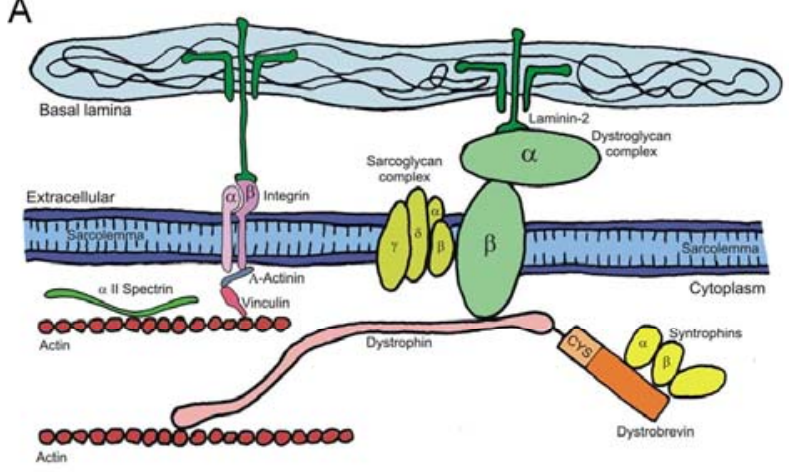

C

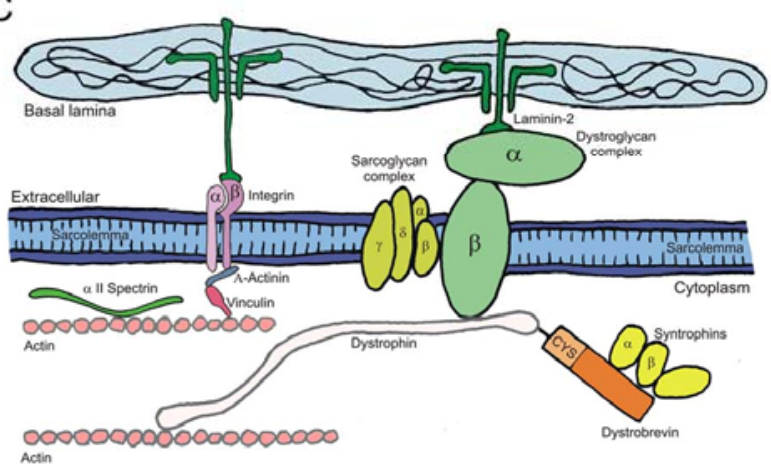

$\mathrm{B}$

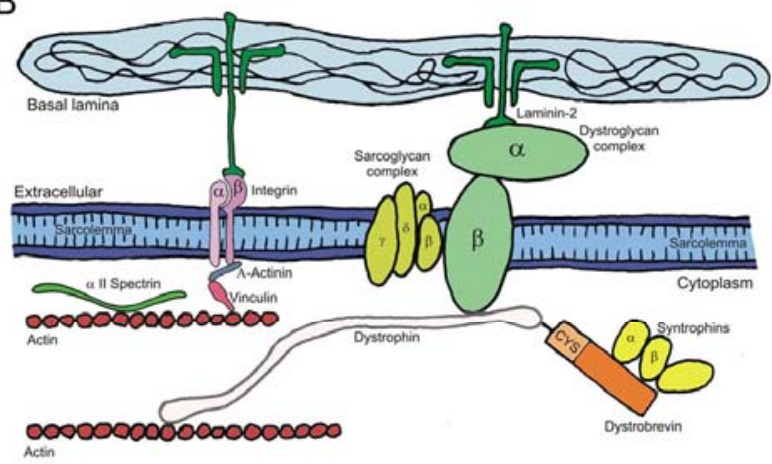

$\mathrm{D}$

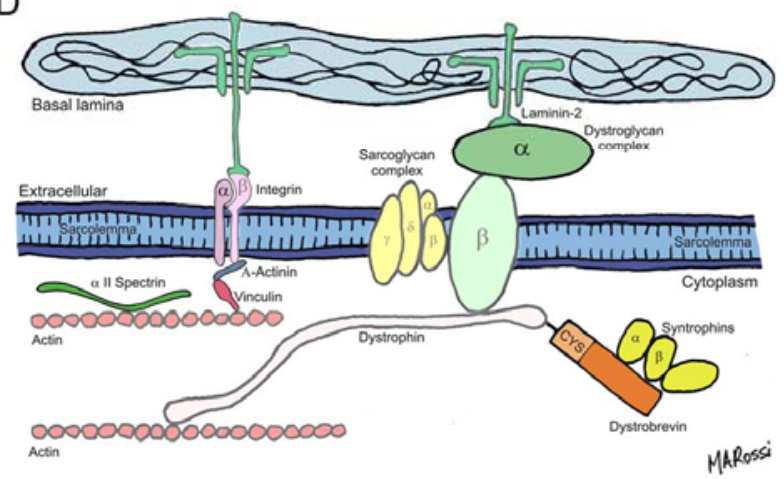

Figura 18: Diagrama esquemático representando a seqüência de eventos observada: A) o complexo de glicoproteínas associadas à distrofina e as integrinas. A distrofina conecta a actina à proteína transmembrana distroglicana. A distroglicana liga-se à matriz extracelular através da laminina. As integrinas também ligam a actina à laminina. B-D) seqüencia de eventos observada. B) primeiro, a perda da distrofina e presença da actina sarcomérica. C) segundo, a perda da distrofina e graus variados de dissolução da actina sarcomérica. D) terceiro, a perda da distrofina, da actina sarcomérica, e redução da expressão da $\beta$-distroglicana, da $\gamma$-sarcoglicana, da $\beta 1$ integrina e da laminina $\alpha-2$. 


\section{REFERÊNCIAS*}

Allikian MJ, Mcnally EM. Processing and assembly of the dystrophin glycoprotein complex. Traffic. 2007;8:177-183.

Armstrong SC, Latham CA, Shivell C, Ganote CE. Ischemic loss of sarcolemmal dystrophin and spectrin: correlation with myocardial injury. J Mol Cell Cardiol. 2001;33:1165-1179.

Berges A, Van Nassauw L, Timmermans JP, Vrints C. Time-dependent expression patterm of nitric oxide and superoxide after myocardial infarction in rats. Pharmacol Res. 2007;5:72-79.

Berk BC, Fujiwara K, Lehoux S. ECM remodeling in hypertensive heart disease. J Clin Invest. 2007;117:568-575.

Calderwood DA, Shattil SJ, Ginsberg MH. Integrins and actin filaments: reciprocal regulation of cell adhesion and signaling. J Biol Biochem. 2000;275:22607-22610.

Chappel CI, Rona G, Balazs T, Gaudry R. Severe myocardial necrosis produced by isoproterenol in the rat. Arch Int Pharmacodyn Ther. 1959;122:123-128.

Csapó Z, Dusek J, Rona G. Early alterations of the cardiac muscle cells in Isoproterenolinduced necrosis. Arch Pathology. 1972;93:356-365.

Danialou G, Comtois AS, Dudley R, Karpati G, Vincent G, Des Rosiers C, Petrof BJ. Dystrophin-deficient cardiomyocytes are abnormally vulnerable to mechanical stressinduced contractile failure and injury. FASEB J. 2001;15:1655-1657.

Delon I, Brown NH. Integrins and the actin cytoskeleton. Curr Opin Cell Biol. 2007;19:4350 .

Dhalla KS, Rupp H, Beamish RE, Dhalla NS. Mechanisms of alterations in cardiac membrane $\mathrm{Ca}^{2+}$ transport due to excess cathecolamines. Cardiovasc Drugs Ther. 1996;10:231-238.

Ervasti JM, Ohlendieck K, Kahl SD, Gaver MG, Campbell KP. Deficiency of $\alpha$ glycoprotein component of the dystrophin complex in dystrophic muscle. Nature. 1990;345:315-319.

Ferrans VJ, Hibbs RG, Black WC, Weilbaecher DG. Isoproterenol-induced myocardial necrosis. A histochemical and electron microscopic study. Am Heart J. 1964;68:71-90.

* As referências estão de acordo com:

International Committee of Medical Journal Editors (Vancouver Style). Disponível em: http://www.icmje.org 
Fishbein MC, Kulber D, Stancl M, Edwalds G. Distribution of fibrinogen and albumin in normal, ischaemic, and necrotic myocardium during the evolution of myocardial infarction: an immunohistochemical study. Cardiovasc Res. 1986;20:36-41.

Fleckenstein A, Frey M, Fleckenstein-Grün G. Consequences of uncontrolled calcium entry and its prevention with calcium antagonists. Eur Heart J. 1983;4:43-50.

Ganote CE, Armstrong SC. Dystrophin-associated protein complex and heart failure. Lancet. 2002;359:905-906.

Grimm D, Elsner D, Schunkert H, Pfeifer M, Griese D, Bruckschlegel G, Muders F, Riegger GAJ, Kromer EP. Development of heart failure following isoproterenol administration in the rat: role of renin-angiotensin system. Cardiovasc Res. 1998;37:91100 .

Gun C, Mady C. Inotrópicos não-digitálicos. In: Batlouni M, Ramires, JAF. Farmacologia e terapêutica cardiovascular. São Paulo: Editora Atheneu, 1999; p. 109.

Hack AA, Lam MY, Cordier L, Shoturma DI, Ly CT, Hadhazy MA, Hadhazy MR, Sweeney HL, Mcnally EM. Differential requirement for individual sarcoglycans and dystrophin in the assembly and function of the dystrophin-glycoprotein complex. J Cell Sci. 2000;113:2535-2544.

Handforth CP. Isoproterenol-induced myocardial infarction in animals. Arch Pathol. 1962;73:161-165.

Hein S, Kostin S, Heling A, Maeno Y, Schaper J. The role of the cytoskeleton in the heart failure. Cardiovasc Res. 2000;45:273-278.

Henry MD, Campbell KP. Dystroglycan: an extracellular matrix receptor linked to the cytoskeleton. Curr Opin Cell Biol. 1996;8:625-631.

Heydemann A, Huber JM, Kakkar R, Wheeler MT, Mcnally EM. Functional nitric oxide synthase mislocalization in cardiomyopathy. J Mol Cell Cardiol. 2004;36:213-223.

Heydemann A, Mcnally EM. Consequences of disrupting the dystrophin-sarcoglycan complex in cardiac and skeletal myopathy. Trends Cardiovasc Med. 2007;17:55-59.

Hikoso S, Ikeda Y, Yamaguchi O, Takeda T, Higuchi Y, Hitotami S, Kashiwase K, Yamada M, Asahi M, Matsumura Y, Nishida K, Matsuzaki M, Hori M, Otsu K. Progression of heart failure was suppressed by inhibition of apoptosis signal-regulating kinase 1 via transcoronary gene transfer. J Am Coll Cardiol. 2007;50:453-462.

Kaprielian RR, Stevenson S, Rothery SM, Cullen MJ, Dphil MA, Severs NJ. Distinct patterns of dystrophin organization in myocyte sarcolemma and transverse tubules of normal and diseased human myocardium. Circulation. 2000;101:2586-2594. 
Kahn DS, Rona G, Chappel CI. Isoproterenol-induced cardiac necrosis. Ann N Y Acad Sci. 1969;156:285-293.

Kawada T, Masui F, Tezuka A, Ebisawa T, Kumagai H, Nakazawa M, Toyo-Oka T. A novel scheme of dystrophin disruption for the progression of advanced heart failure. Biochim Byophys Acta. 2005;1751:73-81.

Kido M, Otani H, Kyoi S, Sumida T, Fujiwara H, Okada T, Imamura H. Ischemic preconditioning-mediated restoration of membrane dystrophin during reperfusion correlates with protection against contraction-induced myocardial injury. Am J Physiol Heart Circ Physiol. 2004;287:H81-90.

Kostin S, Scholz D, Shimada T, Maeno Y, Mollnau H, Hein S, Schapper J. The internal and external protein scaffold of the T-tubular system in cardiomyocytes. Cell Tissue Res. 1998;294:449-460.

Kostin S, Hein S, Arnon E, Scholz D, Schaper J. The cytoskeleton and related proteins in the human failing heart. Heart Fail Rev. 2000;5:271-280.

Lapidos KA, Kakkar R, Mcnally EM. The dystrophin glycoprotein complex: signaling strength and integrity for the sarcolemma. Circ Res. 2004;94:1023-1031.

Massion PB, Pelat M, Belge C, Balligand JL. Regulation of the mammalian heart function by nitric oxide. Comp Biochem Physiol A Mol Integr Physiol. 2005;142:144-150.

Matsumura K, Arai K, Zhong D, Saito F, Fukuta-Ohi H, Maekawa R, Yamada H, Shimizu T. Disruption of dystroglycan axis by $\beta$-dystroglycan processing in cardiomyopathic hamsters. Neuromuscul Disord. 2003;13:796-803.

Mcnally E, Allikian M, Wheeler MT, Mislow JM, Heydemann A. Cytoskeletal defects in cardiomyopathy. J Mol Cell Cardiol. 2003;35:231-241.

Milei J, Rapaport M. Localization by autoradiography of tritiated isoproterenol in infarctlike lesions of rat myocardium. Am Heart J. 1976;92:351-355.

Milei J, Nuñes RG, Rapaport M. Pathogenesis of isoproterenol-induced myocardial lesions: its relation to human coagulative myocytolysis. Cardiology. 1978;63:139-151.

Miyazato H, Biro S, Setoguchi M, Maeda M, Tashiro T, Nakao S, Tanaka H. Abnormal immunostaining for dystrophin in isoproterenol-induced acute myocardial injury in rats: evidence for change in dystrophin in the absence of genetic defect. J Mol Cell Cardiol. 1997;29:1217-1223.

Mohan P, Bloom S. Lipolysis is an important determinant of isoproterenol-induced myocardial necrosis. Cardiovasc Pathol. 1999;8:255-261.

Morgan EE, Faulx MD, McElfresh TA, Kung TA, Zawaneh MS, Stanley WC, Chandler MP, Hoit BD. Validation of echocardiographic methods for assessing left ventricular 
dysfunction in rats with myocardial infarction. Am J Physiol Heart Circ Physiol. 2004;287:H2049-2053.

Noronha-Dutra AA, Steen EM. Lipid peroxidation as a mechanism of injury in cardiac myocytes. Lab Invest. 1982;47:346-353.

Noronha-Dutra AA, Steen EM, Woolf N. The early changes induced by isoproterenol in the endocardium and adjacent myocardium. Am J Pathol. 1984;114:231-239.

Oliviéro P, Chassagne C, Salichon N, Corbier A, Hamon G, Marotte F, Charlemagne D, Rappaport L, Samuel JL. Expression of laminin alpha-2 chain during normal and pathological growth of myocardium in rat and human. Cardiovasc Res. 2000;46:346-355.

Osadchii OE, Norton GR, Mckechnie R, Deftereos D, Woodiwiss AJ. Cardiac dilatation and pump dysfunction without intrinsic myocardial systolic failure following chronic $\beta$ adrenoceptor activation. Am J Physiol Heart Circ Physiol. 2007;292:H1898-H1905.

Reichenbach DD, Benditt EP. Catecholamines and cardiomyopathy: the pathogenesis and potential importance of myofibrilar degeneration. Hum Pathol. 1970;1:125-150.

Remondino A, Kwon SH, Communal C, Pimentel DR, Sawyer DB, Singh K, Colucci WS. $\beta$-adrenergic receptor-stimulated apoptosis in cardiac myocytes is mediated by reactive oxygen species/c-jun $\mathrm{NH}_{2}$ terminal kinase-dependent activation of mitochondrial pathway. Circ Res. 2003;92:136-138.

Rodríguez M, Cai W-J, Kostin S, Lucchesi BR, Schaper J. Ischemia depletes dystrophin and inhibits protein synthesis in the canine heart: Mechanisms of myocardial ischemic injury. J Mol Cell Cardiol. 2005;38:723-733.

Rona G, Chappel CL, Balazs T, Gaudry R. An infract-like myocardial lesion and other toxic manifestations produced by Isoproterenol in the rat. Arch Pathol. 1959;67:443-455.

Rona G, Boutet M, Hüttner I, Peters H. Pathogenesis of isoproterenol-induced myocardial alterations: functional and morphological correlates. Recent Adv Stud Cardiac Struct Metab. 1973;3:507-525.

Rona G. Catecholamine cardiotoxicity. J Mol Cell Cardiol. 1985;17:291-306.

Rosenmann E, Gazenfield E, Laufer A, Davies AM. Isoproterenol induced myocardial lesions in the immunized and non-imunized rat. 1. Histopathological lesions in normal rats. Path Microbiol (Basel). 1964;27:303-309.

Ross RS, Borg TK. Integrins and the myocardium. Circ Res. 2001;88:1112-1119.

Ross R S. The extracelular connections: the role of integrins in myocardial remodeling. J Card Fail. 2002;8:S326-S331. 
Rozec B, Noireaud J, Trochu JN, Gauthier C. Place of beta 3-adrenoceptors among other beta-adrenoceptor subtypes in the regulation of the cardiovascular system. Arch Mal Couer Vaiss. 2003;96:905-913.

Rybakova IN, Patel JR, Ervasti JM. The dystrophin complex forms a mechanically strong link between the sarcolemma and costameric actin. J Cell Biol. 2000;150:1209-1214.

Sadoshima J, Izumo S. The cellular and molecular response of cardiac myocytes to mechanical stress. Annu Rev Physiol. 1997;59:551-571.

Schlesinger MJ, Reiner L. Focal myocytolysis of the heart. Am J Pathol. 1955;31:443-459.

Schiller NB, Shah PM, Crawford M, DeMaria A, Devereux R, Feigenbaum H, Gutgesell H, Reichek N, Shan D, Schnittger I, et al. Recommendations for quantification of the left ventricle by two-dimensional echocardiography. American Society of Echocardiography, Committee on Standards, Subcommittee on quantification of two-dimensional Echocardiograms. J Am Soc Echocardiogr. 1989;2:358-367.

Singal PK, Dhillon KS, Beamish RE, Dhalla NS. Protective effect of zinc against catecholamine-induced myocardial changes electrocardiographic and ultrastructural studies. Lab Invest. 1981;44:426-433.

Singal PK, Kapur N, Dhillon KS, Beamish RE, Dhalla NS. Role of the free radicals in catecholamine-induced cardiomyopathy. Can J Physiol Pharmacol. 1982;60:1390-1397.

Singal PK, Beamish RE, Dhalla NS. Potencial oxidative pathways of catecholamines in the formation of lipid peroxides and genesis of heart disease. Adv Exp Med Biol.

1983;161:391-401.

Stevenson S, Rothery S, Cullen MJ, Severs NJ. Spatial relationship of the C-terminal domains of dystrophin and beta-dystroglycan in cardiac muscle support a direct molecular interaction at the plasma membrane interface. Circ Res. 1998;82:82-93.

Straub V, Rafael JA, Chamberlain JS, Campbell KP. Animal models of muscular dystrophy show different patterns of sarcolemmal disruption. J Cell Biol. 1997;139:375-385.

Straub V, Duclos F, Venzke DP, Lee JC, Cutshall S, Leveille CJ, Campbell KP. Molecular pathogenesis of muscle degeneration in the delta-sarcoglycan-deficient hamster. Am J Phathol. 1998;153:1623-1630.

Tappia PS, Hata T, Hozaima L, Sandhu MS, Panagia V, Dhalla NS. Role of oxidative stress in catecholamine-induced changes in cardiac sarcolemmal $\mathrm{Ca}^{2+}$ transport. Arch Biochem Biophys. 2001;387:85-92.

Tidball JG, Albrecht DE, Lokensgard BE, Spencer MJ. Apoptosis precedes necrosis of dystrophin-deficient muscle. J Cell Sci. 1995;108:2197-2204. 
Towbin JA. The role of cytoskeletal proteins in cardiomyopathies. Curr Opin Cell Biol. 1998;10:131-139.

Toyo-Oka T, Kawada T, Nakata J, Xie H, Urabe M, Masui F, Ebisawa T, Tezuka A, Iwasawa K, Nakajima T, Uehara Y, Kumagai H, Kostin S, Schapper J, Nakazawa M, Ozawa K. Translocation and cleavage of myocardial dystrophin as a common pathway to advanced heart failure: a scheme for the progression of cardiac dysfunction. Proc Natl Acad Sci U S A. 2004;101:7381-7385.

Turner PR, Fong PY, Denetclaw WF, Steinhardt RA. Increased calcium influx in dystrophic muscle. J Cell Biol. 1991;115:1701-1712.

van Der Flier A, Sonnenberg A. Function and interaction of integrins. Cell Tissue Res. 2001;305:285-298.

van Amerongen MJ, Harmsen MC, van Rooijen N, Petersen AH, Van Luyin MJA. Macrophage depletion impairs wound healing and increases left ventricular remodeling after myocardial injury in mice. Am J Pathol. 2007;170:818-829.

Vatta M, Stetson SJ, Perez-Verdia A, Entman ML, Noon GP, Torre-Amione G, Bowles NE, Towbin JA. Molecular remodeling of dystrophin in patients with end-stage cardiomyopathies and reversal in patients on assistance-device therapy. Lancet. 2002;359:936-941.

Wasmeier GH, Melnychenko I., Voigt J-U, Zimmermann WH, Eschenhagen T, Schineis N, Reulbach U, Flachskampf FA, Daniel WG, Nixdorff U. Reproducibility of transthoracic echocardiography in small animals using clinical equipment. Coron Artery Dis. 2007;18:283-291.

Watson LE, Sheth M, Denyer RF, Dostal DE. Baseline echocardiographic values for adult male rats. J Am Soc Echocardiogr. 2004;17:161-167.

Weytjens C, Cosyns B, D’hooge J, Gallez C, Droogmans S, Lahoute T, Franken P, Van Camp G. Doppler myocardial imaging in adult male rats: reference values and reproducibility of velocity and deformation parameters. Eur J Echocardiogr. 2006;7:411417.

Winder SJ. The complexities of dystroglycan. Trends Biochem Sci. 2001;26:118-124.

Xi H, Shin WS, Suzuki J, Nakajima T, Kawada T, Uehara Y, Nakazawa M, Toyo-Oka T. Dystrophin Disruption might be related to myocardial cell apoptosis caused by Isoproterenol. J Cardiovasc Pharmacol. 2000;36:S25-29.

Xiong D, Yajima T, Lim B-K, Stenbit A, Dublin A, Dalton ND, Summers-Torres D, Molkentin JD, Duplain H, Wessely R, Chen J, Knowlton KU. Inducible cardiac-restricted expression of enteroviral protease $2 \mathrm{~A}$ is sufficient to induce dilated cardiomyopathy. Circulation. 2007;115, 94-102. 
Yoshida H, Takahashi M, Koshimizu M, Tanonaka K, Oikawa R, Toyo-Oka T, Takeo S. Decrease in sarcoglycans and dystrophin in failing heart following acute myocardial infarction. Cardiovasc Res. 2003;59:419-427.

Yunge L, Bruneval P, Cokay MS, Berry B, Peters H, Poulsen R, Hüttner I. Perturbation of the sarcolemmal membrane in isoproterenol-induced myocardial injury of the rat.: Permeability and freeze-fracture studies in vivo and in vitro. Am J Pathol. 1989;134:171185.

Zhang Y, Takagawa J, Sievers RE, Khan MF, Viswanathan MN, Springer ML, et al. Validation of wall motion score and myocardial performance indexes as novel techniques to asses cardiac function in mice after myocardial infarction. Am J Physiol Heart Circ Physiol. 2007;292:H1187-92. 


\section{ANEXOS}




\title{
ANEXO A - Carta do Comitê de Ética
}

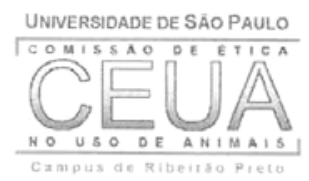

\author{
UNIVERSIDADE DE SÃO PAULO \\ Campus de Ribeirão Preto \\ Comissão de Ética no Uso de Animais
}

\section{E R T I F I C A D O}

Certificamos que o trabalho (Protocolo $n^{\circ}$ 06.1.480.53.0), intitulado: "Efeito da Injeção de Isoproterenol nas Proteínas que Conferem Estabilidade Estrutural da Membrana de Cardiomiócito de Ratos", de autoria de Érica Carolina Campos, por estar de acordo com os Princípios Éticos na Experimentação Animal adotado pela Comissão de Ética no Uso de Animais (CEUA) do Campus de Ribeirão Preto - USP foi aprovado em reunião da CEUA de 11.09.06.

Ribeirão Preto, 12 de setembro de 2006

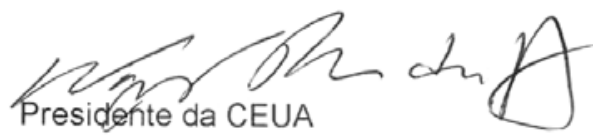

Prof. Dr. Wagner Ferreira dos Santos

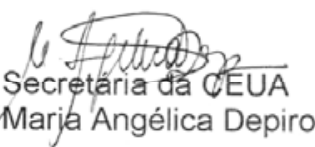

Av. Bandeirantes, 3900 - CEP 14040-900 - Ribeirăo Preto - São Paulo Fone: (16) 6024469 - Fax: (16) 6337964 


\section{ANEXO B - Reagentes e Soluções}

A) SOLUÇÃO DE $\mathrm{NaCl}$ 0,9\% - SALINA

Foram dissolvidos $9 \mathrm{~g}$ de $\mathrm{NaCl}$ em 1 litro de água destilada.

B) PBS

Foram dissolvidos $8,17 \mathrm{~g}$ de $\mathrm{NaCl}, 0,36 \mathrm{~g}$ de fosfato de sódio monobásico, 1,05 $\mathrm{g}$ de fosfato de sódio dibásico e completado para um volume final de 1 litro com água destilada. $\mathrm{O} \mathrm{pH}$ foi ajustado para 7,4 com $\mathrm{NaOH} 2 \mathrm{M}$.

C) SOLUÇÃO ÁLCOOL-ÁCIDO

Foram misturados $99 \mathrm{ml}$ de álcool $70 \%$ e $1 \mathrm{ml}$ de ácido clorídrico concentrado.

D) SOLUÇÃO EOSINA-FLOXINA

Foram misturados $62,5 \mathrm{ml}$ de solução estoque de eosina a $1 \%, 6,25 \% \mathrm{ml}$ de solução estoque de floxina a $1 \%$ e $487,5 \% \mathrm{ml}$ de ácido acético glacial.

E) SOLUÇÃO PRÉ-INFILTRADORA

Foram misturadas partes iguais de solução infiltradora e álcool 100\%.

F) SOLUÇÃO INFILTRADORA

Foram misturados $100 \mathrm{ml}$ de Historesin (Leica Instruments $\mathrm{GmbH}$, Heidelberg, Alemanha) e $1 \mathrm{~g}$ de Hardner (Leica Instruments GmbH, Heidelberg, Alemanha). 


\section{G) SOLUÇÃO PARA INCLUSÃO}

Foram misturados $15 \mathrm{ml}$ de solução infiltradora e $1 \mathrm{ml}$ de Hardner II (Leica Instruments GmbH, Heidelberg, Alemanha).

\section{H) SOLUÇÃO AZUL DE TOLUIDINA}

Foram misturados $1 \mathrm{~g}$ de azul de toluidina e $1 \mathrm{~g}$ de tetraborato de sódio a $100 \mathrm{ml}$ de água destilada quente. A solução foi estocada, à temperatura ambiente, em frasco de vidro vedado. 


\section{ANEXO C - Fixadores e Colorações}

A) FORMOL À 3,7\% EM PBS

Foram misturados $10 \mathrm{ml}$ de formol a 3,7\% e $90 \mathrm{ml}$ de PBS para um volume final de 100 $\mathrm{ml}$.

\section{B) COLORAÇÃO DE HEMATOXILINA DE HARRIS}

As lâminas são deixadas na solução de hematoxilina por 5 a 8 segundos e lavadas com 2 trocas de água corrente. Em seguida, são passadas pela água amoniacal por 30 segundos e lavadas com 2 trocas de água corrente. Por último, são desidratadas, diafanizadas e montadas.

\section{B) COLORAÇÃO HEMATOXILINA E EOSINA}

As lâminas foram desparafinizadas em série decrescente de álcoois e lavadas em água corrente. Em seguida, coradas pela Hematoxilina de Harris por 3-5 minutos. Lavadas em água corrente e diferenciadas em solução álcool ácido a 1\% e lavadas por 15 minutos. Após, foram coradas em solução de eosina-floxina por 10 a 30 segundos e passadas em álcool 95\% para a retirada do excesso de corante. As lâminas foram desidratadas, diafanizadas e montadas.

\section{C) COLORAÇÃO AZUL DE TOLUIDINA}

Os cortes foram cobertos com algumas gotas de solução corante por 3-5 minutos em platina aquecida à $55-60^{\circ} \mathrm{C}$, lavados em água corrente e secos em platina aquecida. 